\title{
DOES TERROR THREATEN HuMAN RightS? EVIDENCE FROM PANEL DATA
}

\author{
AXEL DREHER \\ MARTIN GASSEBNER \\ LARS-H. R. SIEMERS \\ CESIFO WORKING PAPER No. 1935 \\ CAtegory 2: Public ChOICE \\ MARCH 2007 \\ An electronic version of the paper may be downloaded \\ - from the SSRN website: \\ - from the RePEc website: \\ - from the CESifo website: \\ www.SSRN.com \\ www.RePEc.org \\ www.CESifo-group.de
}




\title{
DOES TERROR THREATEN HUMAN RigHTS? EVIDENCE FROM PANEL DATA
}

\begin{abstract}
The paper presents a political economy model linking terror and governments' respect for human rights. Using panel data for 111 countries over the period 1973-2002, we then empirically analyze whether and to what extent terror affects human rights - measured by three indices covering a wide variety of human rights aspects. According to our results, terror substantially diminishes governments' respect for basic human rights such as absence of extrajudicial killings, political imprisonment, and torture. To some extent, civil rights are also restricted as a consequence of terrorism, while we find no effect of terrorism on empowerment rights.
\end{abstract}

JEL Code: D74, F52, P48.

Keywords: terrorism, human rights, civil liberties, suicide attacks.

\begin{tabular}{|c|c|}
\hline $\begin{array}{r}\text { Ax } \\
E \\
\text { KOF \& Depar } \\
\text { Technolos } \\
\text { Wei } \\
80 \\
\text { S } \\
\text { mail@ }\end{array}$ & $\begin{array}{l}\text { gement, } \\
\text { iics }\end{array}$ \\
\hline $\begin{array}{c}\text { Martin Gassebner } \\
\text { ETH Zurich } \\
\text { KOF \& Department of Management, } \\
\text { Technology and Economics } \\
\text { Weinbergstr. } 35 \\
\text { 8092 Zurich } \\
\text { Switzerland } \\
\text { gassebner@kof.ethz.ch }\end{array}$ & $\begin{array}{c}\text { Lars-H. R. Siemers } \\
\text { RWI Essen } \\
\text { Hohenzollernstr. 1-3 } \\
\text { 45128 Essen } \\
\text { Germany } \\
\text { siemers@rwi-essen.de }\end{array}$ \\
\hline
\end{tabular}

February 2007

We thank Ivo Bischoff, Christian Bjørnskov, Christian Conrad, Justina Fischer, Simon Luechinger, Jan-Egbert Sturm and participants at the KOF research seminar for helpful comments on an earlier draft. Parts of the paper have been written while Dreher was visiting the Centre for Economic Studies (CES). 


\section{Introduction}

Governments' respect for human rights has opposing effects on national security. On the positive side, granting inalienable rights such as the freedom of speech, freedom of religion, the guarantee of impartial treatment in court, the protection from invasion of privacy and - even more importantly - the absence of torture, extrajudicial killings and political imprisonment enables citizens to live in freedom and safety, and to express potential political critique in non-violent form. But on the negative side, greater human rights increase a country's vulnerability to external and internal threats. Consequently, the net effect of human rights on national security is not obvious.

In Western democracies, the majority of leading politicians seem to endorse the negative view on the consequences of human rights, at least concerning the threat of fundamentalist religious terror. U.S. President Bush, for instance, explicitly formulated objections against a legislation in 2005 which prohibits torture and inhumane treatment of detainees anywhere in the world, as this would hamper the ability of U.S. authorities to obtain information (Amnesty International 2006). Until the U.S. Supreme Court rendered this practice unconstitutional, prisoners in Guantánamo Bay, Cuba, were neither treated as prisoners of war nor as "ordinary" prisoners. ${ }^{1}$ They were denied all basic human rights as well as treatment according to the Geneva Convention. Furthermore, as reported by Risen and Lichtblau (2005), President Bush authorized the National Security Agency to eavesdrop telephone and email communication between the U.S. and abroad without warrants starting in 2002, severely violating basic human rights.

In the U.K., the Prevention of Terrorism Act 2005 allows government ministers to issue control orders restricting the liberty, movement and activities of people purportedly suspected of terrorism-related activity. In Australia, similar legislations have recently been enacted. Thus, anecdotal evidence suggests that countries respond to terrorism and threat to their Western values by diminishing those very rights they wanted to protect in the first place. ${ }^{2}$

\footnotetext{
${ }^{1}$ Hamdan v. Rumsfeld, U.S. Supreme Court, June 29, 2006; 548 U.S.__, 126 S.Ct. 2749(2006).

2 Restrictive anti-terror laws have been passed not only in Western societies. According to Amnesty International (2006), for instance, China and India have recently passed even stricter human rightsrestricting anti-terrorism laws.
} 
However, though anecdotal evidence abounds, systematic analysis is lacking. ${ }^{3}$ The question whether terrorism systematically reduces human rights is yet unsettled. This is the question our paper addresses. Specifically, we employ panel data for 111 countries over the period 1973-2002 to analyze whether and to what extent terror does - on average - reduce human rights.

To anticipate our main results, we find that terror diminishes governments' respect for basic human rights such as the principle of absence of extrajudicial killings, political imprisonment, and torture. To some extent, civil rights are also restricted as a consequence of terrorism. Our basic results are extremely robust as to how we specify our model, as Extreme Bounds Analysis with almost 23,000 regressions shows. We find no effect of terror on empowerment rights, i.e. "positive rights," such as political participation and freedom of movement or religion.

We continue as follows. The next section presents our theoretical motivation. We introduce our hypotheses in section three and our measures of human rights and terror in section four. In section five we explain our method of estimation; section six presents the results, while we test the robustness of these results in section seven. The final section concludes.

\section{Model}

Let there be a continuum of citizens normalized to (a mass of) unity in every country, indexed by $c$. Citizens in every country $c$ are of different types, indexed by $i$. Every type $i$ has the same basic and quasi-linear preferences over the publicly provided goods "security," labeled $s$, and "human rights," labeled $h$, which is given by

$$
u_{c}^{i}=s_{c}^{i}+H_{c}\left(h_{c}\right)
$$

where $H_{c}(\cdot)$ is a country-specific concave and increasing function. Citizens differ in their perception regarding the link between human rights and security. Therefore, the types $i$ differ in the level of perceived security $s_{c}$. We assume that every type of citizen develops

\footnotetext{
${ }^{3}$ This seems to be true for the literature on human rights in general. In the words of Kaufmann (2004: 2) "the literature on human rights is overwhelmingly prose-rich and data-poor." For a recent exception see Dreher and Siemers (2006).
} 
beliefs $s_{c}^{i}=s_{c}^{i}\left(h_{c}\right)$. As long as $h_{c}$ represents domestic human rights, it is plausible to assume that most citizens believe that $\frac{\partial s_{c}^{i}\left(h_{c}\right)}{\partial h_{c}}<0$, where the security perception monotonously decreases with increasing $h_{c}$, that is, if $h_{c}>0$, citizens are willing to pay a prize in terms of lower security to enjoy greater human rights. ${ }^{4}$ However, regarding human rights abuses abroad, it is also plausible that disrespect of human rights reduces security at home (an example is the human rights disaster at Abu Ghraib). We assume that the distribution of beliefs $s_{c}^{i}\left(h_{c}\right)$ is such that the cumulative distribution function is continuous. With these preliminaries settled it is easy to find that type $i$ 's bliss point is determined by the level of human rights $h_{c}$ :

$$
\frac{\partial H_{c}\left(h_{c}\right)}{\partial h_{c}}=-\frac{\partial s_{c}^{i}\left(h_{c}\right)}{\partial h_{c}}
$$

We assume that governments want to remain in power. In order to achieve this goal, the government of a country $c$ has to win the support of a fraction $\pi \in(0,1]$ of the society. We assume that providing human rights respect involves costs, so that the government has no incentive to provide more human rights than the level required to win the support of that fraction $\pi$ of society that demands the lowest level of human rights respect. Therefore, the level of human rights in our model society, denoted $h_{c} *$, is determined by the belief referring to the correlation between security and human rights of the pivotal citizen who completes the critical mass of citizens, $\pi .^{5}$

Obviously the perception of security is, ceteris paribus, negatively influenced by factors like "number of terror attacks" and "number of persons killed in terror attacks." Let all these aspects of terror which decrease the perception of security be represented by the exogenously given vector $t^{c}=\left(t_{1}^{c}, \mathrm{~K}, t_{n}^{c}\right)$. Then, we have to extend our model such

\footnotetext{
${ }^{4}$ Of course, not all types of human rights are likely to reduce national security, some may even improve it. However, considering the aggregate level of governments' respect for human rights, our assumption appears plausible.

${ }^{5}$ Suppose, for instance, belief $s_{c}^{i}\left(h_{c}\right)=\left(\sigma_{c}^{i} h_{c}\right)^{-1}$ and $\pi=1 / 2$. Then the pivotal citizen is determined by the median $\sigma_{c}^{m}$.
} 
that the individual beliefs become modified toward $s_{c}^{i}=s_{c}^{i}\left(h_{c}, t^{c}\right)$ with $\frac{\partial s_{c}^{i}(\cdot)}{\partial t_{j}^{c}}<0$, for all $i \in[0,1]$ and $j=1, \mathrm{~K}, n$. Given a particular level of human rights, terror attacks decrease the level of security and hence the (marginal) prize of human rights in terms of security rises:

$$
\frac{\partial^{2} s_{c}^{i}(\cdot)}{\partial h_{c} \partial t_{j}^{c}}<0
$$

for all $i \in[0,1]$ and $j=1, \mathrm{~K}, n$. It directly follows that the equilibrium level of human rights decreases in the aftermath of terror attacks, because condition (3) also holds for the pivotal citizen in the aftermath of terror attacks. The pivotal citizen balances between people who believe that the prize of human rights in terms of security is too high, and thus demand a lower level of $h$, and the group of people who believe that this prize of human rights is so low that an increase in the level of human rights is optimal.

We assume decreasing marginal utilities. Therefore, in countries with higher levels of human rights, a massive decrease in the perceived national security via terror attacks will, all other things equal, cause stronger decreases as in countries with lower levels of human rights, because human rights are not scarce and the marginal utility loss per unit, i.e. the price, is lower. Terror attacks change the perceived security of the pivotal citizen, who changes her or his beliefs on the link between security and human rights respect; as a consequence, the political equilibrium level of human rights respect decreases.

Note that our model covers the median-voter model (Black 1948; Downs 1957; Persson and Tabellini 2000, Chap. 3) as a subcase. In the median-voter model we have $\pi=1 / 2$ and the government competes with the opposition in electoral competition. ${ }^{6}$ In nondemocratic regimes, the governments also compete with the opposition for the support of the citizens, as it is threatened by potential revolution and uprisings (Acemoglu and Robinson 2001). In order to stay in power, that is to prevent uprisings

\footnotetext{
${ }^{6}$ Applied to the median-voter model, there are (at least) two competing parties: one party prefers a low level of human rights and higher human rights involve costs, and another party, which prefers high levels of human rights and lower levels of human rights involve costs.
} 
and revolution, it has to please a critical mass of the society, which can be, depending on the specific country, any fraction $\pi \in(0,1]$.

The governing groups in all countries are mainly interested to remain in power. In a nondemocratic regime, most part of society is excluded from political power. Still, the government depends on the support of the majority or at least a powerful minority. While in democracies parties compete for election, in nondemocratic regimes, the government to some extent must please parts of the citizenry in order to stay in power. In our model, we therefore refer to the "pivotal individual," which is the marginal individual the government has to win in order to stay in power, for instance the median voter in a democracy.

Applied to U.S. policy in the aftermath of September 11, 2001 (9/11), for instance, U.S. citizens were shocked by the attack. Their security perception was basically extinguished and they were willing to accept, or demanded, a lower level of human rights to increase security. In polls, president Bush received approval rates of 60 to 90 percent in the times when his administration "engineered the biggest expansion in executive power since the days of Franklin Roosevelt" with the Patriot Act, comprising, e.g., the right of monitoring telephone calls without explicit approval from the courts, reading private e-mails, prying into library records and establishing military tribunals (The Economist 2006a: 20-21). The threat of terror led to a situation in which national security became the major political topic in elections. Similar developments can be observed all over the Western World - though only few countries, such as Great Britain, acted as strictly as the US. One has to bear in mind that this pattern of behavior already existed in pre-9/11 years. After the 1993 bombings of the World Trade Center and the federal building in Oklahoma City the Antiterrorism Act of 1996 was passed. Cole and Dempsey (2002: 117) rank the Act as "some of the worst assaults on civil liberties [prior to the 2001 antiterrorism measures]."

However, considering the threat of terror in the context of the Basque or Northern Ireland conflict, the Spanish and British governments eventually decided to improve the human rights situation after a period of confrontation, because they - or rather the majority of the voters - realized that what occurred was a vicious circle of violence. That is, it is also possible that the median voter believes greater human rights to increase 
security. The Palestinian issue saw both developments, human rights improvements and more frequent human rights violations.

Note that the trade-off relevant for political outcome is the subjectively perceived link between human rights and terror, and not necessarily the "actual" trade-off between respect for human rights and terrorism. ${ }^{7}$ In the US, for instance, not a single terrorist was found by rounding up hundreds of foreigners, most of them Muslims, after 9/11 and holding them without charge, sometimes for months (The Economist 2006b). Hence, citizens may have adaptive expectations and learn that at least some anti-terrorist measures do not improve national security. ${ }^{8}$ In the next section, we explicitly formulate three major hypotheses derived from our model, which we are going to confront with data further below.

\section{Hypotheses}

Overall, it seems reasonable to expect that the relationship between terrorism and human rights is negative. Governments seem to react to an increase in terrorism by constraining the freedom and privileges of their citizens, and our model suggests that this reaction may be based on the demand for security of the majority of citizens. Stricter surveillance and control makes it harder to exchange secret information and (radical) ideas. As stricter controls impair terrorists' ability to plan attacks, the public is more willing to accept them in times of increased threat. Citizens may correct their beliefs about the probability of a terror attack in their country upwards when the country experienced an attack. Consequently, they are more willing to accept a decrease in the level of human rights in order to enhance security. Moreover, terrorists might take attacks as indicator of the government's weakness, in turn improving their confidence to be able to successfully threaten or even overthrow the government. Consequently, the government has an incentive to decrease human rights respect in order to be better able to monitor terrorist movements. The illustrative example of President Bush initially objecting to a bill

\footnotetext{
${ }^{7}$ Empirical research suggests an inverted U-shape relationship between political rights and terrorism (Eubank and Weinberg 2001; Abadie 2006).

${ }^{8}$ However, recent polls in Britain and the US suggest that most voters still feel their governments are not doing enough to counter terrorism (The Economist 2006b).
} 
prohibiting the torture and inhumane treatment of detainees anywhere in the world because it would negatively affect the possibility of obtaining information (Amnesty International, 2006) demonstrates that even fundamental human rights and values are put into perspective if they are expected to reduce national security. Based on this reasoning we expect:

\section{Hypothesis 1: An increase in the level of terrorist activity leads to a reduction in the level of human rights.}

Given the decreasing marginal utilities in our model, we do not expect, however, this reduction to be linear. In countries with high levels of human rights the marginal price of security in terms of human rights is low as human rights are not scarce. We therefore expect:

\section{Hypothesis 2: An increase in the level of terrorist activity leads to a sharper reduction in the level of human rights in countries with high levels of human rights.}

Although this reasoning appears straight forward, one can also argue, however, in the opposite direction. In our model, it is equally possible that the pivotal citizen believes the increase in human rights to improve national security. Terror attacks might be perceived as reactions to bad human rights situations (all over the world). ${ }^{9}$ Governments thus might give in to terrorism that pretendedly aims at improving the human rights situation. Of course, giving in to kidnapping and other forms of blackmailing may be timeinconsistent, as one becomes vulnerable to further attempts. However, states did give in to kidnapping events in the past. In October 1972, for instance, Germany released the three Palestine survivors of the terror attacks at the Olympic Games in Munich after an airplane had been hijacked. In March 1975, Germany released five prisoners from the terror scene after the politician Peter Lorenz had been kidnapped. Although the German government does not give in to political demands anymore, it is still willing to pay money

\footnotetext{
${ }^{9}$ For a discussion of unilateral vs. multilateral actions of terrorists and states see Sandler (2005).
} 
in exchange for the release of kidnapped citizens - and other countries do the same. Therefore, the probability of states giving in to political demands is greater than zero. Consequently, Krueger and Malečková (2003) find, analyzing a survey conducted by the Palestinian Center for Policy Research in 2001, that a majority of Palestinians living in the West Banks and Gaza Strip believe that their achieved rights could not have been possible by negotiations alone. Our examples regarding the Basque and Northern Ireland conflict also suggest that terror is a means that might, eventually, improve human rights levels at particular places. In our model, it is equally well possible that the pivotal citizen believes that human rights respect improves national security. Hence, we state the counter-hypothesis:

\section{Hypothesis 3: An increase in terrorist activity leads to an increase in the level of human rights.}

Obviously, hypotheses 1 and 3 might to some extent be valid at the same time, especially taking into account that every terrorism problem has its own specific origin. While we cannot empirically distinguish between them, what we can do is estimating which of those effects dominates. In other words, what we estimate is the average net effect resulting from the two opposing effects. This is what we turn to below.

\section{Measuring Human Rights and Terror}

Our definition of citizens' human rights follows Cingranelli and Richards (1999). Their Human Rights Dataset (CIRI, Cingranelli and Richards 2006) provides quantitative information on government respect for 13 internationally recognized human rights, on an annual basis and for almost all countries of the world. Cingranelli and Richards focus on actual human rights-related actions of governments, including all government agents such as police and military. Their database draws from two sources, the U.S. Department of State's Country Reports on Human Rights Practices, and from the Amnesty International Report, offering detailed descriptions of human rights practices.

In particular, the CIRI data refer to extrajudicial killings, people who have disappeared for political reasons, torture, political imprisonment, freedom of speech, freedom of religion, freedom of movement, freedom of assembly and association, 
political participation, worker's rights, women's political rights, women's economic rights, and women's social rights. Each variable is coded on an ordinal scale, ranging between 0-2 and, depending on the variable considered, 0-4, where higher values reflect better ratings in the respective human rights dimension.

In this paper we mainly focus on two composite indicators proposed in Cingranelli and Richards (1999) and Richards, Gelleny and Sacko (2001). The first composite index refers to physical integrity rights - it is the additive of absence of torture, extrajudicial killings, political imprisonments, and disappearance, on a scale from 0-8 (so-called "negative rights"). The second composite refers to empowerment rights and comprises the freedom of movements, freedom of speech, workers' rights, political participation, and freedom of religion indicators, ranging from 0-10 ( "positive rights").

\section{Figure 1: Development of Physical Integrity over time}

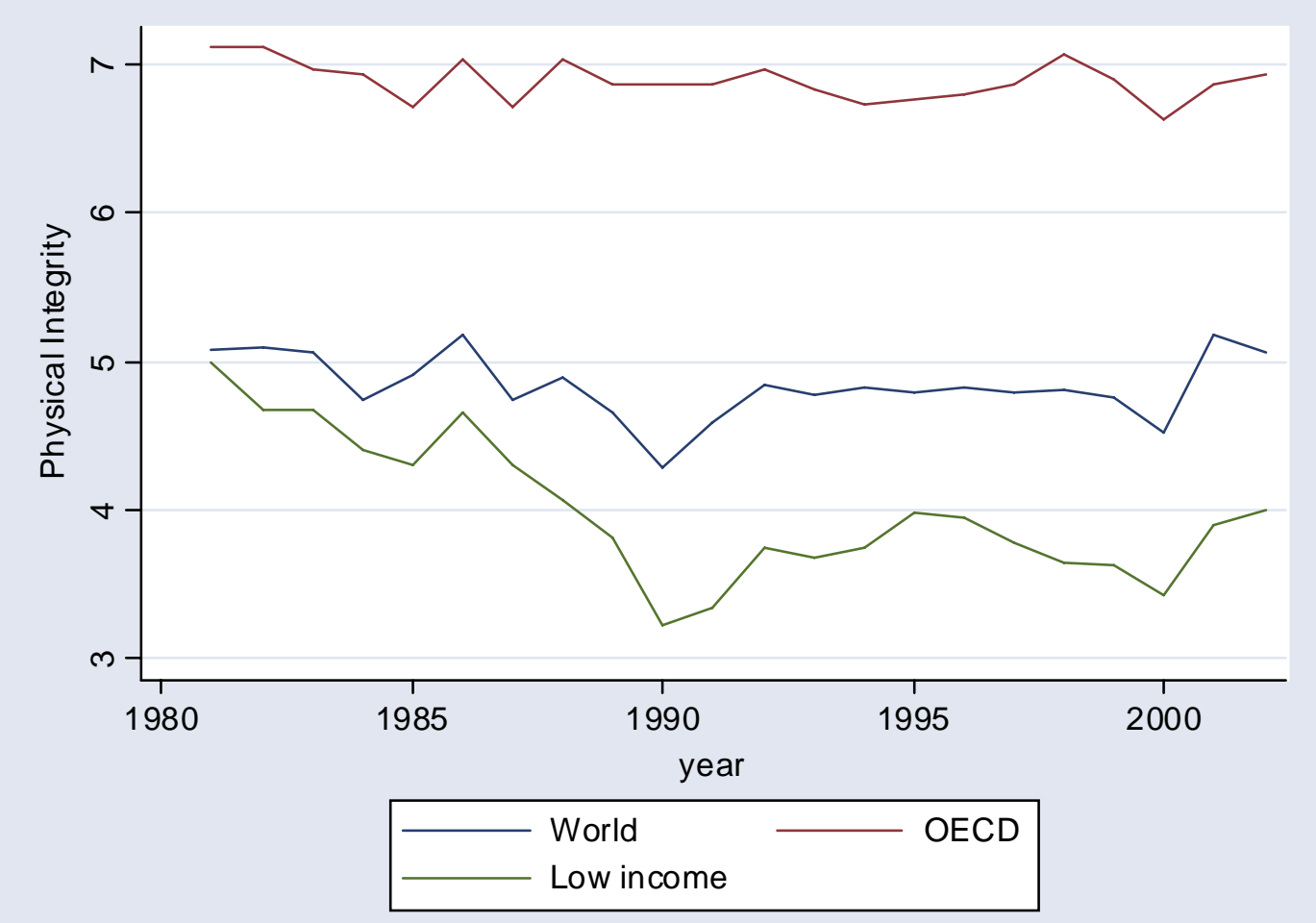

The upper line in Figure 1 shows the time path of the unweighted average of the physical integrity index for the OECD countries over the years 1981-2004. The lower line 
represents the average for low income countries, ${ }^{10}$ while the unweighted world average is shown in the middle. The number of countries covered rises from 125 in 1981 to 179 in 2004. The figure shows that the mean of the world index was fairly constant over time at a value of around 5 with, however, a substantial drop around 1990. The average for the OECD countries is also rather constant over time, at a higher level of around 7. Figure 1 shows that there is some variation in physical integrity for developing countries, with a substantial negative trend. The level of physical integrity peaked in 1981 at 5 , fell to a low point of 3.2 in 1990, rose to 4 in 1995, and after declining again until 2000 is slightly below 4 in 2004.

\section{Figure 2: Development of Empowerment Rights over time}

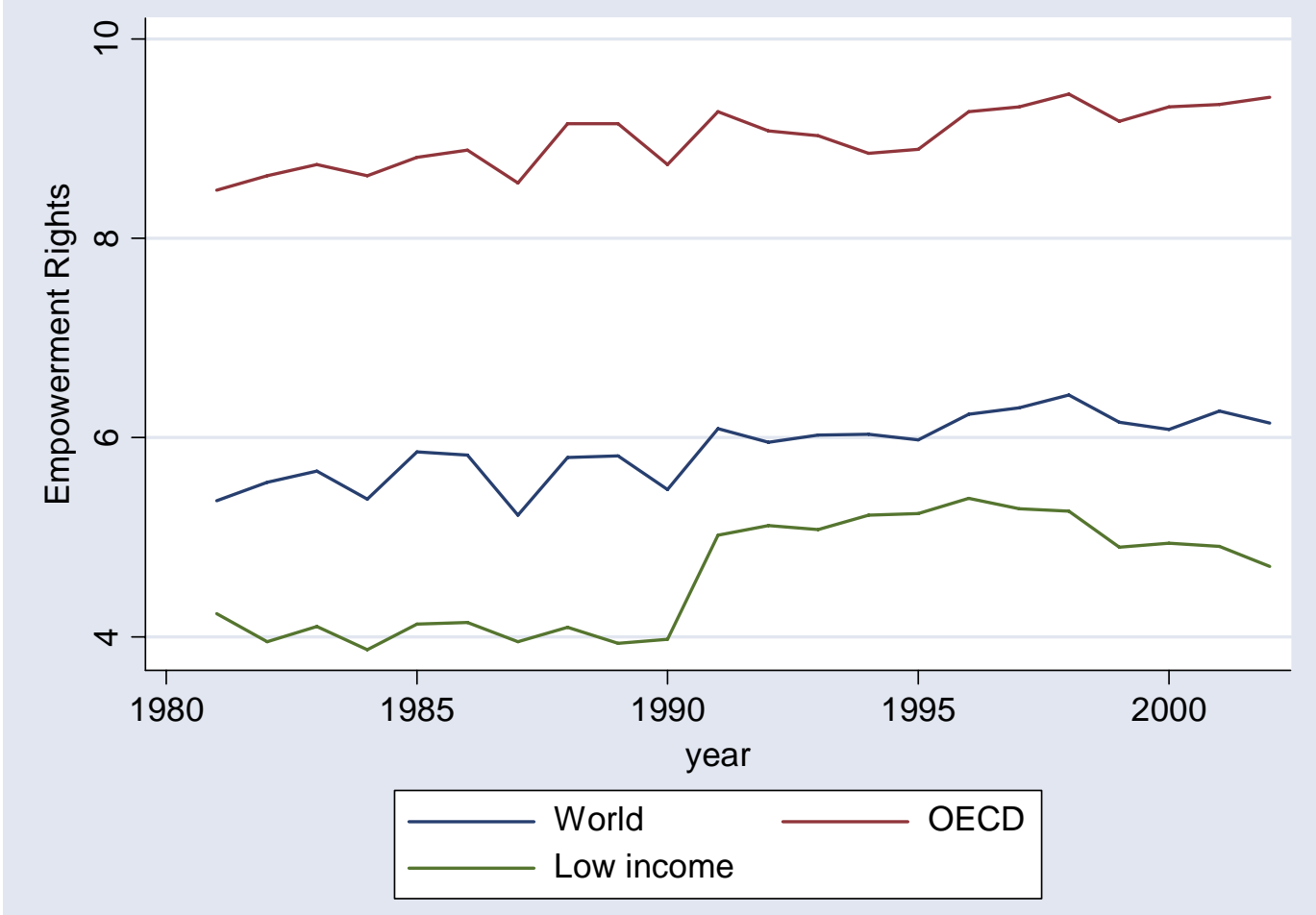

Figure 2 shows the development of empowerment rights. As can be seen, the average level of empowerment rose steadily over the period of observation, with similar developments in developing and OECD countries. The most substantial increase in

\footnotetext{
${ }^{10}$ Countries with low income are those with 2004 GNI per capita of a maximum of 825 US\$, according to the definition of the World Bank (2006).
} 
empowerment was experienced in 1990, in particular in low income countries. ${ }^{11}$ The index mean is 4.6 for low income countries, more than 9 in OECD countries, and 5.9 for the world sample. Since 1996 we observe a negative trend in low-income countries. The world sample contains 130 countries in 1981, and 181 in 2004.

\section{Figure 3: Development of Civil Liberties over time}

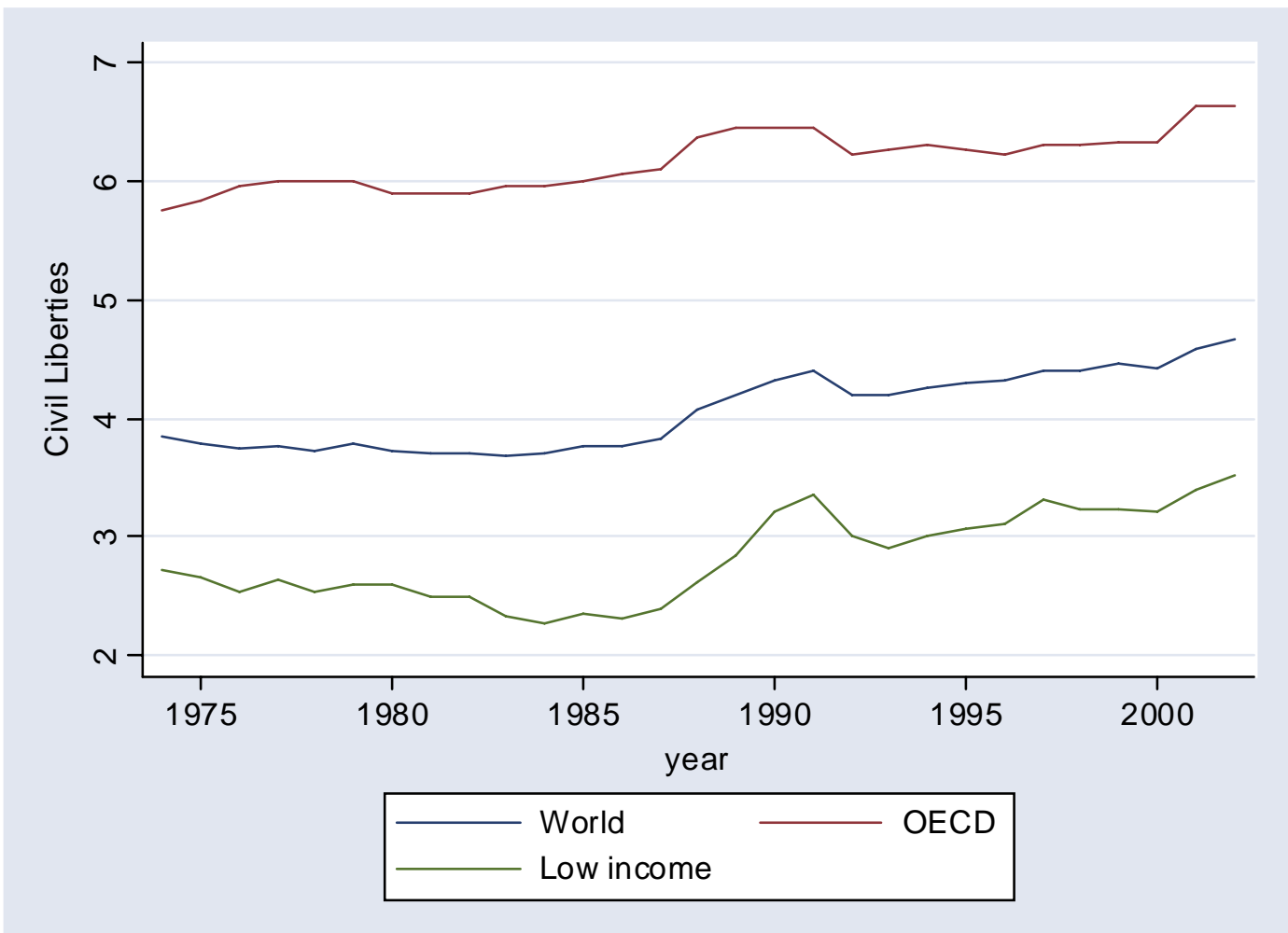

As a third proxy for human rights we employ the civil liberties indicator provided by Freedom House (2005). The survey based index combines four subcategories: freedom of expression and belief, associational and organizational rights, rule of law, and personal and individual rights. The rule of law subcategory measures whether equal treatment, police control and absence of torture prevails. To some extent, the index thus

\footnotetext{
${ }^{11}$ The apparent increase in low income countries from 1990 to 1991 is mainly driven by Mali, Democratic Republic of Congo and Togo (increases of 4, 5 and 9 points, respectively).
} 
combines empowerment and physical integrity rights. ${ }^{12}$ We rescale the original index so that a value of seven indicates greatest freedom while one is the lowest score.

Figure 3 shows the development of civil liberties over time. Clearly, all three groups of countries display a positive trend. In the early 1990s, the index peaks, in particular in low-income countries. In these countries, the increase has been particularly pronounced over the years 1987 to 1992 , with an index score of roughly 4.5. In 1993, in all three groups the civil rights index returned to its longer term trend.

Turning to our measure of terrorist activity, we employ data provided in the MIPT Terrorism Knowledge Base. ${ }^{13}$ The Terrorism Knowledge Base integrates data from the RAND Terrorism Chronology and RAND-MIPT Terrorism Incident databases, the Terrorism Indictment database, and DFI International's research on terrorist organizations. $^{14}$

The Terrorism Knowledge Base defines terror as "violence, or the threat of violence, calculated to create an atmosphere of fear and alarm." The focus of terror is to discourage the opposition from acting at their free will. The motives for engaging in terror are political while the acts themselves are generally conducted in a way that will achieve maximum publicity. Moreover, terrorist acts are mostly intended to create more than immediate physical damage - a long-time situation of fear and intimidation. For an extensive summary on the various effects of terrorism see Frey et al. (2007). For a theoretical model of the macroeconomic effects and an empirical application see Eckstein and Tsiddon (2004).

We extract the number of terror events for each country and year as our variable of main interest. ${ }^{15} \mathrm{We}$ also employ the number of suicide attacks and the number of people killed in a certain year and country. Suicide attacks are likely to be perceived as particularly threatening. They might be more effective from the terrorists' point of view

\footnotetext{
${ }^{12}$ The correlation between physical integrity and empowerment is 0.51 , while it is 0.59 between integrity and civil liberties, and 0.82 between empowerment and civil liberties.

${ }^{13}$ Available at: http://www.tkb.org/.

${ }^{14}$ There are also different sources for terrorism data. We choose MIPT because it combines various sources. For a detailed discussion on measurement of terrorism we refer to Frey and Luechinger (2005).

${ }^{15}$ Territories are assigned to the country formally governing the territory. Kashmir and the Persian Gulf are excluded as it is not obvious to which country they should be assigned to.
} 
as it is hard to fight someone who is explicitly willing to sacrifice the own life. Suicide attacks might thus provoke particularly harsh reactions by the government concerned. ${ }^{16}$ The same is likely to be true when the attacks are more severe, i.e., when more people are killed. Given that the database covers the whole world, we assign zeros to all countries and years without data.

\section{Figure 4: Development of Terror over time}

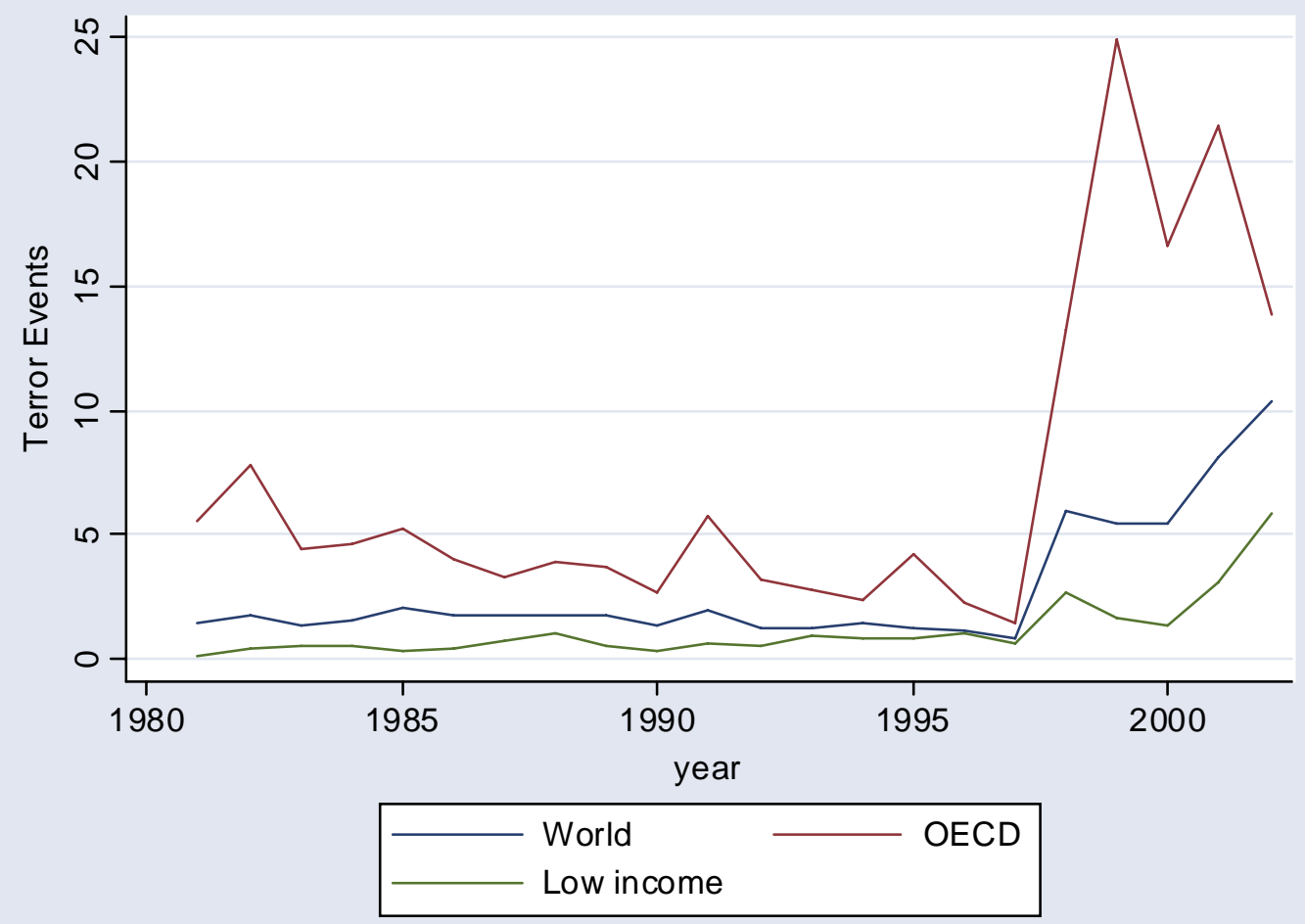

Figure 4 shows how terror has evolved over time. OECD countries experience the highest amount of terror while low income countries encounter the lowest value. ${ }^{17}$ Particularly noteworthy is the rise across all country groups in the recent past. ${ }^{18}$

\footnotetext{
${ }^{16}$ For a summary of studies on suicide bombing see, e.g., Sandler (2003).

${ }^{17}$ For time-series studies on the occurrence and distribution of terrorism see Enders and Sandler (2005, 2006).

${ }^{18}$ The increase is driven in part by the explicit inclusion of domestic terror in the dataset from 1998 onward. We discuss this issue in section 7.
} 


\section{Method}

We estimate pooled time-series cross-section (panel data) regressions. The data extend to a maximum of 111 countries and cover the years 1973-2002. Since some of the data are not available for all countries or years, the panel data are unbalanced and the number of observations depends on the choice of explanatory variables.

To test our hypotheses we estimate equations of the following form:

$$
\text { RIGHTS }_{i, t}=\alpha \text { RIGHTS }_{i, t-1}+\beta \text { Terror }_{i, t}+\gamma Z_{i, t-1}+u_{i, t},
$$

where RIGHTS $_{i, t}$ represents our measure of human rights, and Terror $_{i, t}$ is the respective measure of terrorist attacks in country $i$ at year $t$ (i.e., the number of events, the number of suicide attacks and, respectively, the number of people killed). $Z$ is a vector of control variables as introduced below. Note that we also include the lagged dependent variable, as human rights develop only slowly over time and the lagged dependent variable turns out to be highly significant (see e.g. Dreher and Siemers 2006). Following the previous literature, we estimate our model employing ordered probit, with clustering at the country level and robust standard errors. All regressions include dummies for each year, which are highly significant.

In selecting our control variables, we follow the robustness analysis in Dreher and Siemers (2006). Based on a general-to-specific approach and extensive robustness tests employing Extreme Bounds Analysis, Dreher and Siemers suggest the following variables as robust predictors of a country's level of physical integrity rights: the logarithm of a countries' population, its degree of democracy, dummies for income, and dummies for legal origin.

Our measure of democracy is from the Polity IV database as provided by Gurr et al. (2003). It represents the difference between a country's democracy and autocracy score running from -10 to 10 with higher numbers indicating higher levels of democracy. ${ }^{19}$ Population is taken from the World Bank's (2006) World Development Indicators, legal origin follows Easterly and Sewadeh (2001), while the income classification is according to the World Bank (2006). The next section reports the results.

\footnotetext{
19 The index is based on competitiveness and openness of executive recruitment, competitiveness and regulation of political participation, and constraints on chief executives.
} 


\section{Results}

Column 1 of Table 1 replicates the baseline model of Dreher and Siemers (2006) for the physical integrity index. As can be seen, the quantitative variables are significant at the one percent level. The sets of dummy variables indicating income and, respectively, legal origin, are both jointly significant at the one percent level. According to the results, government respect for human rights is higher with smaller population and greater democracy. The former finding is consistent with the notion that lower surveillance costs, e.g. because of a smaller population, allow the government to allocate more human rights. Moreover, higher levels of democracy reduce the government's possibility to increase security by restraining rights.

Table 1: Human rights and terror events, ordered probit, 111 countries

\begin{tabular}{lcccccc}
\hline & $(1)$ & $(2)$ & $(3)$ & $(4)$ & $(5)$ & $(6)$ \\
& physical & empowerment & civil & physical & empowerment & civil \\
\hline Lagged endogenous & 0.540 & 0.538 & 1.827 & 0.536 & 0.538 & 1.825 \\
& $(23.67)^{\star \star \star}$ & $(20.54)^{\star \star \star}$ & $(17.38)^{\star \star \star}$ & $(23.44)^{\star \star \star}$ & $(20.56)^{\star \star \star}$ & $(17.33)^{\star \star \star}$ \\
Income lower middle & -0.034 & -0.067 & 0.094 & -0.033 & -0.067 & 0.097 \\
& $(0.42)$ & $(0.83)$ & $(1.37)$ & $(0.39)$ & $(0.83)$ & $(1.42)$ \\
Income upper middle & 0.249 & 0.016 & 0.296 & 0.256 & 0.016 & 0.300 \\
& $(2.32)^{\star \star}$ & $(0.15)$ & $(2.99)^{\star \star \star}$ & $(2.36)^{\star \star}$ & $(0.15)$ & $(3.03)^{\star \star \star}$ \\
Income high OECD & 1.102 & 0.580 & 1.398 & 1.134 & 0.580 & 1.419 \\
& $(6.68)^{\star \star \star}$ & $(2.74)^{\star \star \star}$ & $(7.80)^{\star \star \star}$ & $(6.91)^{\star \star \star}$ & $(2.75)^{\star \star \star}$ & $(7.96)^{\star \star \star}$ \\
Income high & 0.031 & -0.377 & -0.017 & 0.078 & -0.377 & 0.007 \\
& $(0.20)$ & $(3.47)^{\star \star \star}$ & $(0.15)$ & $(0.56)$ & $(3.37)^{\star \star \star}$ & $(0.06)$ \\
Legal origin British & -0.909 & -0.359 & -0.285 & -0.887 & -0.359 & -0.270 \\
& $(4.80)^{\star \star \star}$ & $(1.04)$ & $(0.73)$ & $(4.70)^{\star \star \star}$ & $(1.04)$ & $(0.69)$ \\
Legal origin French & -1.009 & -0.316 & -0.400 & -0.979 & -0.316 & -0.379 \\
& $(5.04)^{\star \star \star}$ & $(0.90)$ & $(1.03)$ & $(4.92)^{\star \star \star}$ & $(0.90)$ & $(0.97)$ \\
Legal origin Socialist & -0.704 & -0.464 & -0.413 & -0.682 & -0.464 & -0.402 \\
& $(3.08)^{\star \star \star}$ & $(1.22)$ & $(1.01)$ & $(3.00)^{\star \star \star}$ & $(1.22)$ & $(0.98)$ \\
Legal origin German & -1.135 & -0.490 & -0.572 & -1.141 & -0.490 & -0.571 \\
& $(3.71)^{\star \star \star}$ & $(1.22)$ & $(1.33)$ & $(3.71)^{\star \star \star}$ & $(1.22)$ & $(1.32)$ \\
Population (log) & -0.202 & -0.101 & -0.080 & -0.198 & -0.101 & -0.076 \\
& $(9.16)^{\star \star \star}$ & $(4.04)^{\star \star \star}$ & $(4.37)^{\star \star \star}$ & $(8.99)^{\star \star \star}$ & $(3.98)^{\star \star \star}$ & $(4.18)^{\star \star \star}$ \\
Democracy & 0.016 & 0.076 & 0.045 & 0.018 & 0.076 & 0.046 \\
& $(2.79)^{\star \star \star}$ & $(10.23)^{\star \star \star}$ & $(5.27)^{\star \star \star}$ & $(3.09)^{\star \star \star}$ & $(10.22)^{\star \star \star}$ & $(5.34)^{\star \star \star}$ \\
Number of terror events & & & & -0.003 & -0.000 & -0.002 \\
& & & & $(4.73)^{\star \star \star}$ & $(0.05)$ & $(2.43)^{\star \star}$ \\
\hline Observations & 2217 & 2219 & 3218 & 2217 & 2219 & 3218 \\
Years & $1982-2002$ & $1982-2002$ & $1973-2002$ & $1982-2002$ & $1982-2002$ & $1973-2002$ \\
Pseudo R ${ }^{2}$ & 0.31 & 0.37 & 0.65 & 0.31 & 0.37 & 0.65 \\
\hline & & & & & &
\end{tabular}

Robust z statistics in parentheses

* significant at 10\%; ** significant at 5\%; ${ }^{* \star \star}$ significant at $1 \%$

Dummy for each year included. 
Table 2: Human rights and terror, ordered probit, 111 countries

\begin{tabular}{|c|c|c|c|c|c|c|}
\hline & $\begin{array}{c}(1) \\
\text { physical }\end{array}$ & $\begin{array}{c}(2) \\
\text { empowerment }\end{array}$ & $\begin{array}{l}\text { (3) } \\
\text { civil }\end{array}$ & $\begin{array}{c}(4) \\
\text { physical }\end{array}$ & $\begin{array}{c}\text { (5) } \\
\text { empowerment }\end{array}$ & $\begin{array}{l}\text { (6) } \\
\text { civil }\end{array}$ \\
\hline Lagged endogenous & $\begin{array}{c}0.539 \\
(23.63)^{\star \star \star}\end{array}$ & $\begin{array}{c}0.538 \\
(20.55)^{\star \star \star}\end{array}$ & $\begin{array}{c}1.826 \\
(17.37)^{\star \star \star}\end{array}$ & $\begin{array}{c}0.540 \\
(23.57)^{\star \star \star}\end{array}$ & $\begin{array}{c}0.538 \\
(20.54)^{\star \star \star}\end{array}$ & $\begin{array}{c}1.827 \\
(17.37)^{\star \star \star}\end{array}$ \\
\hline Income lower middle & $\begin{array}{l}-0.036 \\
(0.44)\end{array}$ & $\begin{array}{l}-0.067 \\
(0.83)\end{array}$ & $\begin{array}{l}0.094 \\
(1.37)\end{array}$ & $\begin{array}{l}-0.033 \\
(0.40)\end{array}$ & $\begin{array}{l}-0.067 \\
(0.83)\end{array}$ & $\begin{array}{l}0.094 \\
(1.38)\end{array}$ \\
\hline Income upper middle & $\begin{array}{c}0.249 \\
(2.31)^{\star \star}\end{array}$ & $\begin{array}{l}0.016 \\
(0.15)\end{array}$ & $\begin{array}{c}0.296 \\
(2.99)^{\star \star \star}\end{array}$ & $\begin{array}{c}0.252 \\
(2.33)^{\star \star}\end{array}$ & $\begin{array}{l}0.016 \\
(0.15)\end{array}$ & $\begin{array}{c}0.296 \\
(2.99)^{\star \star \star}\end{array}$ \\
\hline Income high OECD & $\begin{array}{c}1.102 \\
(6.66)^{\star \star \star}\end{array}$ & $\begin{array}{c}0.581 \\
(2.75)^{\star \star \star}\end{array}$ & $\begin{array}{c}1.398 \\
(7.80)^{\star \star \star}\end{array}$ & $\begin{array}{c}1.113 \\
(6.66)^{\star \star \star}\end{array}$ & $\begin{array}{c}0.579 \\
(2.74)^{\star \star \star}\end{array}$ & $\begin{array}{c}1.399 \\
(7.81)^{\star \star \star}\end{array}$ \\
\hline Income high & $\begin{array}{l}0.057 \\
(0.39)\end{array}$ & $\begin{array}{c}-0.382 \\
(3.41)^{\star \star \star}\end{array}$ & $\begin{array}{l}-0.010 \\
(0.08)\end{array}$ & $\begin{array}{l}0.039 \\
(0.26)\end{array}$ & $\begin{array}{c}-0.375 \\
(3.41)^{\star \star \star}\end{array}$ & $\begin{array}{l}-0.015 \\
(0.13)\end{array}$ \\
\hline Legal origin British & $\begin{array}{c}-0.910 \\
(4.79)^{\star \star \star}\end{array}$ & $\begin{array}{l}-0.359 \\
(1.04)\end{array}$ & $\begin{array}{l}-0.285 \\
(0.73)\end{array}$ & $\begin{array}{c}-0.899 \\
(4.71)^{\star \star \star}\end{array}$ & $\begin{array}{l}-0.359 \\
(1.04)\end{array}$ & $\begin{array}{l}-0.284 \\
(0.73)\end{array}$ \\
\hline Legal origin French & $\begin{array}{c}-1.010 \\
(5.04)^{\star \star \star}\end{array}$ & $\begin{array}{l}-0.316 \\
(0.90)\end{array}$ & $\begin{array}{l}-0.401 \\
(1.03)\end{array}$ & $\begin{array}{c}-1.004 \\
(4.98)^{\star \star \star}\end{array}$ & $\begin{array}{l}-0.317 \\
(0.90)\end{array}$ & $\begin{array}{l}-0.399 \\
(1.03)\end{array}$ \\
\hline Legal origin Socialist & $\begin{array}{c}-0.705 \\
(3.07)^{\star \star \star}\end{array}$ & $\begin{array}{l}-0.464 \\
(1.22)\end{array}$ & $\begin{array}{l}-0.414 \\
(1.01)\end{array}$ & $\begin{array}{c}-0.700 \\
(3.05)^{\star \star \star}\end{array}$ & $\begin{array}{l}-0.465 \\
(1.22)\end{array}$ & $\begin{array}{l}-0.413 \\
(1.01)\end{array}$ \\
\hline Legal origin German & $\begin{array}{c}-1.137 \\
(3.71)^{\star \star \star}\end{array}$ & $\begin{array}{l}-0.490 \\
(1.22)\end{array}$ & $\begin{array}{l}-0.573 \\
(1.33)\end{array}$ & $\begin{array}{c}-1.141 \\
(3.72)^{\star \star \star}\end{array}$ & $\begin{array}{l}-0.491 \\
(1.22)\end{array}$ & $\begin{array}{l}-0.573 \\
(1.33)\end{array}$ \\
\hline Population (log) & $\begin{array}{c}-0.202 \\
(9.10)^{\star \star \star}\end{array}$ & $\begin{array}{c}-0.101 \\
(4.04)^{\star \star \star}\end{array}$ & $\begin{array}{c}-0.080 \\
(4.35)^{\star \star \star}\end{array}$ & $\begin{array}{c}-0.199 \\
(9.01)^{\star \star \star}\end{array}$ & $\begin{array}{c}-0.100 \\
(3.96)^{\star \star \star}\end{array}$ & $\begin{array}{c}-0.079 \\
(4.37)^{\star \star \star}\end{array}$ \\
\hline Democracy & $\begin{array}{c}0.017 \\
(2.92)^{\star \star \star}\end{array}$ & $\begin{array}{c}0.076 \\
(10.21)^{\star \star \star}\end{array}$ & $\begin{array}{c}0.046 \\
(5.27)^{\star \star \star}\end{array}$ & $\begin{array}{c}0.017 \\
(2.84)^{\star \star \star}\end{array}$ & $\begin{array}{c}0.076 \\
(10.26)^{\star \star \star}\end{array}$ & $\begin{array}{c}0.045 \\
(5.27)^{\star \star \star}\end{array}$ \\
\hline Number of suicide attacks & $\begin{array}{c}-0.031 \\
(3.31)^{\star \star \star}\end{array}$ & $\begin{array}{l}0.006 \\
(0.73)\end{array}$ & $\begin{array}{c}-0.013 \\
(3.35)^{\star \star \star}\end{array}$ & & & \\
\hline Number of people killed & & & & $\begin{array}{c}-0.001 \\
(4.47)^{\star \star \star}\end{array}$ & $\begin{array}{r}-0.000 \\
(0.32)\end{array}$ & $\begin{array}{r}-0.000 \\
(0.74) \\
\end{array}$ \\
\hline $\begin{array}{l}\text { Observations } \\
\text { Years }\end{array}$ & $\begin{array}{c}2217 \\
1982-2002\end{array}$ & $\begin{array}{c}2219 \\
1982-2002\end{array}$ & $\begin{array}{c}3218 \\
1973-2002\end{array}$ & $\begin{array}{c}2217 \\
1982-2002\end{array}$ & $\begin{array}{c}2219 \\
1982-2002\end{array}$ & $\begin{array}{c}3218 \\
1973-2002\end{array}$ \\
\hline Pseudo $\mathrm{R}^{2}$ & 0.31 & 0.37 & 0.65 & 0.31 & 0.37 & 0.65 \\
\hline
\end{tabular}

Robust $\mathrm{z}$ statistics in parentheses

* significant at 10\%; ** significant at 5\%; ** significant at $1 \%$

Dummy for each year included.

Relative to Scandinavian legal origin - the omitted variable - respect for human rights is smaller among all other categories - it is lowest in countries with German legal origin. As compared to low income countries, respect for human rights is greater in countries with upper middle income and in high income OECD countries.

Columns 2 and 3 report the same specification for the other two dependent variables, generally confirming the previous results. The exception is the dummies for legal origin which are not jointly significant at conventional levels.

Columns 4 to 6 add the number of terror events in a particular year and country. As the results show, physical integrity rights are restricted as a consequence of terror, strongly supporting our Hypothesis 1, and the same is true for civil rights measured by 
the Freedom House index. The former coefficient is significant at the one percent level, while the latter is significant at the five percent level. Empowerment rights do not seem to be affected by the number of terror events.

Table 2 replicates the analysis substituting the number of terror events by the number of suicide attacks, and respectively, the number of people killed in a certain country and year. Again, the results show some impact of terror on human rights. At the one percent level of significance, suicide attacks restrict human rights as measured by the physical integrity index (column 1) and the civil liberties index (column 3). Empowerment rights, to the contrary, are not significantly affected by suicide attacks (column 2). Turning to the number of people killed, there is a highly significant (and negative) impact on physical integrity rights (column 4), while empowerment rights and civil liberties are not significantly affected.

Table 3: Human rights and number of terror events, marginal effects

\begin{tabular}{|l}
\hline Threshold \\
\hline
\end{tabular}

Civil liberties

\begin{tabular}{|lcccccccc|}
\hline Probability at mean & $1.10 \mathrm{E}-09$ & 0.0001 & 0.0438 & 0.5179 & 0.4309 & 0.0073 & $1.12 \mathrm{E}-07$ & 4.40 \\
\hline Number of terror events & & & & & & & & \\
\hline Marginal effect & $1.28 \mathrm{E}-11$ & $4.15 \mathrm{E}-07$ & 0.0002 & 0.0006 & -0.0007 & $-3.83 \mathrm{E}-05$ & $-1.14 \mathrm{E}-09$ & -0.0010 \\
p-value & 0.57 & 0.22 & 0.03 & 0.02 & 0.02 & 0.08 & 0.45 & 0.02 \\
\hline Number of suicide attacks & & & & & & & & \\
\hline Marginal effect & $8.88 \mathrm{E}-11$ & $2.87 \mathrm{E}-06$ & 0.0012 & 0.0039 & -0.0049 & -0.0003 & $-7.92 \mathrm{E}-09$ & -0.0066 \\
p-value & 0.56 & 0.19 & 0.01 & 0.00 & 0.00 & 0.04 & 0.43 & 0.00 \\
\hline
\end{tabular}

Notes: The marginal effects correspond to the significant coefficients of Tables 1 and 2.

As our dependent variables are ordinal, quantitative interpretation of these results is not straightforward. Still, for the significant coefficients of the terror variables of Tables 1 and 2 we calculate the marginal effects (at the mean of all independent 
variables), as shown in Table $3 .^{20}$ According to the results, an additional terror event reduces the physical integrity index by 0.003 at the expected mean of the dependent variable of 5.2. While this number is far from being negligible, the result also implies that the reduction in human rights is not dramatic. To get a better understanding of the importance of terror, Table 3 also shows the marginal effects for the different levels of physical integrity. It becomes obvious that the effect of terror strongly depends on the level of human rights. For low levels of physical integrity terror increases human rights, while terror reduces rights when governments' respect for physical integrity rights is high. As can be seen, the marginal effects are always significant at the one percent level. These results are in line with our hypotheses. Overall, terror reduces human rights (hypothesis 1). However, the impact becomes generally stronger when human rights are a priori more prevalent (hypothesis 2). Terror even increases human rights when hitting countries with initially low respect for human rights (hypothesis 3 ).

Table 3 also shows the marginal effects of suicide attacks and the number of persons killed. According to the results, the pattern is quite similar as compared to those of the number of events. As anticipated, the magnitude of the marginal effect of suicide attacks is substantially larger than those of a "normal" terror event (almost tenfold). One person killed reduces the level of human rights by almost 0.001 .

Regarding civil liberties, an additional terror event causes a reduction of 0.001 at the expected mean of the dependent variable of 4.4. However, three marginal effects are not significant at conventional levels, while five are significant at the five percent level. An additional suicide attack reduces civil liberties by almost 0.007. Again, the pattern of the marginal effects is generally in line with our hypotheses.

Table 4, finally, presents the results of our investigation of the individual components of physical integrity - the dimension that turned out to be robustly affected by terror attacks. As the individual dimensions vary from 0-2 only, variation among high income countries is extremely low. As a consequence, the results for those countries are completely determined in the ordered probit regressions, and some of the regressions do

\footnotetext{
${ }^{20}$ The rows "probability at mean" represent the expected probabilities of obtaining a given index score when all independent variables are assigned their mean value. Note that the mean value is the same (up to three digits behind the comma) for all terror measures employed.
} 
Table 4: Physical integrity rights and terror, ordered probit, 83 countries, 1982-2002

\begin{tabular}{|c|c|c|c|c|c|c|c|c|c|c|c|c|}
\hline & $\begin{array}{c}(1) \\
\text { disappearences }\end{array}$ & $\begin{array}{l}\text { (2) } \\
\text { kills }\end{array}$ & $\begin{array}{c}(3) \\
\text { imprisonment }\end{array}$ & $\begin{array}{c}(4) \\
\text { torture }\end{array}$ & $\begin{array}{c}\text { (5) } \\
\text { disappearences }\end{array}$ & $\begin{array}{l}\text { (6) } \\
\text { kills }\end{array}$ & $\begin{array}{c}(7) \\
\text { imprisonment }\end{array}$ & $\begin{array}{c}(8) \\
\text { torture }\end{array}$ & $\begin{array}{c}\text { (9) } \\
\text { disappearences }\end{array}$ & $\begin{array}{l}\text { (10) } \\
\text { kills }\end{array}$ & $\begin{array}{c}(11) \\
\text { imprisonment }\end{array}$ & $\begin{array}{c}(12) \\
\text { torture }\end{array}$ \\
\hline Lagged endogenous & $\begin{array}{c}1.061 \\
(15.04)^{\star \star \star}\end{array}$ & $\begin{array}{c}1.121 \\
(17.47)^{\star \star \star}\end{array}$ & $\begin{array}{c}1.108 \\
(16.10)^{\star \star \star}\end{array}$ & $\begin{array}{c}0.904 \\
(15.17)^{\star \star \star}\end{array}$ & $\begin{array}{c}1.076 \\
(15.06)^{\star \star \star}\end{array}$ & $\begin{array}{c}1.133 \\
(17.93)^{\star \star \star}\end{array}$ & $\begin{array}{c}1.106 \\
(16.01)^{\star \star \star}\end{array}$ & $\begin{array}{c}0.914 \\
(15.49)^{\star \star \star}\end{array}$ & $\begin{array}{c}1.070 \\
(15.06)^{\star \star \star}\end{array}$ & $\begin{array}{c}1.131 \\
(17.92)^{\star \star \star}\end{array}$ & $\begin{array}{c}1.108 \\
(16.04)^{\star \star \star}\end{array}$ & $\begin{array}{c}0.915 \\
(15.45)^{\star \star \star}\end{array}$ \\
\hline Income lower middle & $\begin{array}{l}-0.071 \\
(0.60)\end{array}$ & $\begin{array}{l}0.053 \\
(0.50)\end{array}$ & $\begin{array}{l}-0.102 \\
(0.92)\end{array}$ & $\begin{array}{l}-0.104 \\
(0.84)\end{array}$ & $\begin{array}{l}-0.074 \\
(0.64)\end{array}$ & $\begin{array}{l}0.039 \\
(0.37)\end{array}$ & $\begin{array}{l}-0.100 \\
(0.91)\end{array}$ & $\begin{array}{l}-0.133 \\
(1.06)\end{array}$ & $\begin{array}{l}-0.073 \\
(0.62)\end{array}$ & $\begin{array}{l}0.040 \\
(0.38)\end{array}$ & $\begin{array}{l}-0.101 \\
(0.91)\end{array}$ & $\begin{array}{l}-0.124 \\
(0.99)\end{array}$ \\
\hline Income upper middle & $\begin{array}{c}0.248 \\
(2.01)^{\star \star}\end{array}$ & $\begin{array}{c}0.353 \\
(2.62)^{\star \star \star}\end{array}$ & $\begin{array}{l}0.127 \\
(1.08)\end{array}$ & $\begin{array}{l}0.253 \\
(1.64)\end{array}$ & $\begin{array}{c}0.239 \\
(2.00)^{\star *}\end{array}$ & $\begin{array}{c}0.334 \\
(2.53)^{\star \star}\end{array}$ & $\begin{array}{l}0.135 \\
(1.14)\end{array}$ & $\begin{array}{l}0.234 \\
(1.49)\end{array}$ & $\begin{array}{c}0.231 \\
(1.90)^{\star}\end{array}$ & $\begin{array}{c}0.330 \\
(2.50)^{\star *}\end{array}$ & $\begin{array}{l}0.128 \\
(1.07)\end{array}$ & $\begin{array}{l}0.232 \\
(1.48)\end{array}$ \\
\hline Legal origin British & $\begin{array}{l}-0.224 \\
(1.07)\end{array}$ & $\begin{array}{l}-0.235 \\
(1.49)\end{array}$ & $\begin{array}{l}-0.290 \\
(1.51)\end{array}$ & $\begin{array}{l}0.009 \\
(0.05)\end{array}$ & & $\begin{array}{l}-0.238 \\
(1.51)\end{array}$ & $\begin{array}{l}-0.285 \\
(1.50)\end{array}$ & & & $\begin{array}{l}-0.240 \\
(1.51)\end{array}$ & $\begin{array}{l}-0.289 \\
(1.50)\end{array}$ & $\begin{array}{l}0.005 \\
(0.03)\end{array}$ \\
\hline Legal origin French & $\begin{array}{c}-0.404 \\
(2.16)^{\star \star}\end{array}$ & $\begin{array}{c}-0.354 \\
(2.48)^{\star \star}\end{array}$ & $\begin{array}{c}-0.391 \\
(2.07)^{\star \star}\end{array}$ & $\begin{array}{l}-0.059 \\
(0.38)\end{array}$ & $\begin{array}{l}-0.196 \\
(1.75)^{\star}\end{array}$ & $\begin{array}{c}-0.375 \\
(2.60)^{\star \star \star}\end{array}$ & $\begin{array}{c}-0.396 \\
(2.09)^{\star \star}\end{array}$ & $\begin{array}{l}-0.093 \\
(0.83)\end{array}$ & $\begin{array}{l}-0.196 \\
(1.69)^{\star}\end{array}$ & $\begin{array}{c}-0.373 \\
(2.59)^{\star \star \star}\end{array}$ & $\begin{array}{c}-0.393 \\
(2.07)^{\star \star}\end{array}$ & $\begin{array}{l}-0.084 \\
(0.53)\end{array}$ \\
\hline Legal origin Socialist & & & & & $\begin{array}{l}0.223 \\
(1.08)\end{array}$ & & & $\begin{array}{l}-0.000 \\
(0.00)\end{array}$ & $\begin{array}{l}0.223 \\
(1.07)\end{array}$ & & & \\
\hline Population (log) & $\begin{array}{c}-0.177 \\
(5.58)^{\star \star \star}\end{array}$ & $\begin{array}{c}-0.190 \\
(7.70)^{\star \star \star}\end{array}$ & $\begin{array}{c}-0.264 \\
(5.54)^{\star \star \star}\end{array}$ & $\begin{array}{c}-0.198 \\
(6.16)^{\star \star \star}\end{array}$ & $\begin{array}{c}-0.184 \\
(5.89)^{\star \star \star}\end{array}$ & $\begin{array}{c}-0.200 \\
(8.42)^{\star \star \star}\end{array}$ & $\begin{array}{c}-0.263 \\
(5.57)^{\star \star \star}\end{array}$ & $\begin{array}{c}-0.211 \\
(6.52)^{\star \star \star}\end{array}$ & $\begin{array}{c}-0.178 \\
(5.70)^{\star \star \star}\end{array}$ & $\begin{array}{c}-0.198 \\
(8.14)^{\star \star \star}\end{array}$ & $\begin{array}{c}-0.262 \\
(5.49)^{\star \star \star}\end{array}$ & $\begin{array}{c}-0.208 \\
(6.47)^{\star \star \star}\end{array}$ \\
\hline Democracy & $\begin{array}{l}-0.001 \\
(0.16)\end{array}$ & $\begin{array}{l}-0.007 \\
(1.05)\end{array}$ & $\begin{array}{c}0.050 \\
(6.77)^{\star \star \star}\end{array}$ & $\begin{array}{c}0.016 \\
(2.06)^{\star \star}\end{array}$ & $\begin{array}{l}-0.002 \\
(0.30)\end{array}$ & $\begin{array}{l}-0.008 \\
(1.19)\end{array}$ & $\begin{array}{c}0.051 \\
(6.77)^{\star \star \star}\end{array}$ & $\begin{array}{c}0.015 \\
(1.85)^{\star}\end{array}$ & $\begin{array}{c}-0.002 \\
(0.29)\end{array}$ & $\begin{array}{l}-0.008 \\
(1.20)\end{array}$ & $\begin{array}{c}0.050 \\
(6.74)^{\star \star \star}\end{array}$ & $\begin{array}{c}0.014 \\
(1.85)^{\star}\end{array}$ \\
\hline Number of terror events & $\begin{array}{l}-0.006 \\
(1.76)^{\star}\end{array}$ & $\begin{array}{c}-0.008 \\
(3.30)^{\star \star \star}\end{array}$ & $\begin{array}{l}-0.001 \\
(0.28)\end{array}$ & $\begin{array}{l}-0.017 \\
(2.42)^{\star *}\end{array}$ & & & & & & & & \\
\hline Number of suicide attacks & & & & & $\begin{array}{l}-0.141 \\
(1.96)^{\star}\end{array}$ & $\begin{array}{c}-0.131 \\
(2.66)^{\star \star \star}\end{array}$ & $\begin{array}{c}-0.183 \\
(2.86)^{\star \star \star}\end{array}$ & $\begin{array}{l}-1.020 \\
(1.80)^{*}\end{array}$ & & & & \\
\hline Number of people killed & & & & & & & & & $\begin{array}{c}-0.003 \\
(2.47)^{\star \star}\end{array}$ & $\begin{array}{l}-0.002 \\
(1.35)\end{array}$ & $\begin{array}{l}-0.001 \\
(0.94)\end{array}$ & $\begin{array}{l}-0.004 \\
(1.28)\end{array}$ \\
\hline Observations & 1650 & 1641 & 1646 & 1648 & 1650 & 1641 & 1646 & 1648 & 1650 & 1641 & 1646 & 1648 \\
\hline Pseudo $\mathrm{R}^{2}$ & 0.27 & 0.30 & 0.37 & 0.24 & 0.27 & 0.30 & 0.37 & 0.24 & 0.27 & 0.30 & 0.37 & 0.24 \\
\hline
\end{tabular}

Robust $z$ statistics in parentheses

* significant at 10\%; ** significant at $5 \%$; *** significant at $1 \%$

Dummy for each year included. 
not converge. We therefore opted to exclude high income countries from the regressions. The dummy for legal German origin also had to be omitted. Note, however, that the main results are unchanged by the omission of high income countries.

Which dimensions drive the results? According to Table 4, almost all individual dimensions of physical integrity rights are negatively affected by terror. At least at the ten percent level of significance, the number of terror events increases the number of people disappearing, extrajudicial killings, and tortures. Governments restrict physical integrity rights among all dimensions as a consequence of suicide attacks, also at least at the ten percent level of significance. Again, the magnitude of the effect is much larger for suicide attacks. The number of people killed by terrorists increases the number of people disappearing, with a coefficient significant at the five percent level.

To summarize, there is clear evidence that - on average - governments respond to terrorism by restricting those very rights they want to protect in the first place. The next section tests whether the impact of our main variables of interest - physical integrity rights and civil liberties - is robust to the inclusion of additional variables, the method of estimation, and sample period.

\section{Tests for robustness}

We pursue various strategies to test the robustness of the impact of terror events on physical integrity rights and civil liberties. First, we replicate the regression with a dummy for the occurrence of terror in a given country and year in place of the number of terror events. Our results might be driven by the linear relationship we impose for the effect of the number of terror events on physical integrity rights. By assigning the value of one in cases when at least one terror event occurred we circumvent this problem. This comes at the cost of reduced information, however.

As our second test for robustness, we exclude those terror events that can be considered to be marginal. We excluded all events in which no person was physically harmed. More precisely, we excluded events in which the number of persons killed and the number of persons injured were both zero and/or missing. Of course, it is debatable which threshold constitutes a severe event. We choose the lowest threshold possible. While this is 
the most objective threshold from our point of view, we are clearly aware that events in which no one is physically harmed may still have a major impact, e.g. the London bombings of July 21, 2005.

Third, we distinguish between domestic and international terror. A domestic incident is defined as an event in which both the target and the attackers are domestic. To some extent, the consequences of these forms of terrorism might be different. A priori, domestic terror might be more likely to increase governments' respect for human rights (Hypothesis 3), while there is no reason to expect the same for international terror. To the contrary, when it comes to international terrorism, Hypothesis 1 seems more likely to hold.

Fourth, we split our sample in two sub-periods and investigate whether the negative impact of terror events holds. As Figure 4 shows, terrorism increased markedly after 1997. We choose this year as cut-off. The increase is to some extent driven by the explicit inclusion of domestic events from 1998 onwards as noted in the definitions of the MIPT Terrorism Knowledge Base. However, domestic terror events are also reported for several cases prior to 1998 .

To some extent, fifth, our result might be due to reversed causality. When people engage in terrorist activities as a consequence of the human rights situation in their country, low human rights might not be the consequence of terror, but its cause. Tests for endogeneity show, however, that the exogeneity of terror can not be rejected at conventional levels of significance. In choosing instruments for terror, we follow Dreher and Gassebner (2006) showing that countries voting in line with the US in the United Nations General Assembly and countries with more fractionalized governments are more frequently the target of terrorist attacks. When we lag terror events by one year instead of using contemporaneous values, the results also remain unchanged. Still, we deal with the issue of potential endogeneity in some detail and report results estimated with 2SLS (where terror is instrumented with voting behaviour in the General Assembly and government fractionalization) below.

Given that our estimation setup includes the lagged dependent variable, 2SLS estimations may, however, suffer from dynamic panel bias. Therefore, we employ the GMM estimator as suggested by Arellano and Bond (1991), Arellano and Bover (1995), as well as Blundell and Bond (1998) in addition. We present results employing the two-step 
estimator implemented by Roodman (2006) in Stata, including Windmeijer's (2005) finite sample correction. We treat the lagged dependent variable and the terror events as endogenous and the additional covariates as strictly exogenous. As before, we include time dummies in the regression. We report results of the Hansen test on the validity of the instruments used (amounting to a test for the exogeneity of the covariates), and the Arellano-Bond test of first and second order autocorrelation. While autocorrelation of first order has to be present in order for the estimator to be consistent, second-order autocorrelation must be absent. In order to minimize the number of instruments in the regressions we collapse the instruments as suggested in Roodman (2006). Doing so reduces the instruments to 85 (physical integrity) and, respectively, 94 (civil liberties).

In empirical research, an important difficulty is that several models may all seem reasonable given the data, but yield different conclusions about the parameters of interest. Hence, as our final test for robustness, we employ the so-called Extreme Bounds Analysis (EBA) to examine to what extent the number of terror events in a country is a robust determinant of physical human rights. The EBA has been widely used in the economic growth literature and became recently one of the standard tools for robustness analysis in the political economy literature. ${ }^{21}$ The EBA aims to examine how sensitive the estimation results are to the inclusion of additional variables. We estimate equations of the following general form:

$$
\operatorname{RIGHTS}_{i, t}=\alpha M_{i, t}+\beta F_{i, t}+\gamma Z_{i, t}+u_{i, t}
$$

where $M$ is a vector of 'standard' explanatory variables; $F$ is the variable of interest; $Z$ is a vector of up to three (here we follow Levine and Renelt, 1992) possible additional explanatory variables, which according to the literature may be related to the dependent variable; and $u$ is an error term. The extreme bounds test as suggested by Leamer (1983) for variable $F$ states that if the lower extreme bound for $\beta$-i.e. the lowest value for $\beta$ minus two standard deviations - is negative, while the upper extreme bound for $\beta$-i.e. the highest value for $\beta$ plus two standard deviations - is positive, the variable $F$ is not robustly related to $Y$. In our case, the variable of interest is the number of terror events in a certain year and country. The $M$ vector contains the base variables as introduced above. In the $Z$

\footnotetext{
${ }^{21}$ For instance, de Haan and Sturm (2000), Inklaar et al. (2005), and Sturm et al. (2005).
} 
vector, we include the 52 variables suggested in the robustness analysis of Dreher and Siemers (2006). Among them is a dummy for years of war, political variables like the ICRG indicator of political risk, and economic variables like trade and government revenue. Appendix A lists all variables with their definitions and sources.

It is rare in empirical research that we can say with certainty that some model dominates all others in all possible dimensions. In these circumstances, it makes sense to check how sensitive the findings are to alternative modelling choices. The EBA provides a relatively simple means of doing exactly this. ${ }^{22}$ We report the percentage of the regressions in which the coefficient of the variable $F$ is significantly different from zero at the 5 percent level as well as the outcomes of the cumulative distribution function (CDF) test. The CDF test as proposed by Sala-i-Martin (1997) is based on the fraction of the cumulative distribution function lying on each side of zero. $\mathrm{CDF}(0)$ indicates the larger of the areas under the density function either above or below zero; in other words, regardless of whether this is $\operatorname{CDF}(0)$ or $1-\operatorname{CDF}(0)$. So $\operatorname{CDF}(0)$ will always be a number between 0.5 and 1.0. We consider a variable to be robust if the $\operatorname{CDF}(0)$ test statistic $>0.95$, following Sturm and de Haan (2005). ${ }^{23}$

Turning to the results of our robustness tests, Table 5 shows that the impact of terror on physical integrity rights is extremely robust as to how terror events are measured, and the same is true regarding the choice of sample period. In all cases terror reduces

${ }^{22}$ Still, the EBA has been criticized. Sala-i-Martin (1997) rightly argues that the test applied is too strict. If the distribution of $\beta$ has some positive and some negative support, then one is bound to find at least one regression for which the estimated coefficient changes sign if enough regressions are run. Sala-i-Martin therefore suggests to analyze the entire distribution of the estimated $\beta$ coefficients.

${ }^{23}$ Recently, Sala-i-Martin et al. (2004) proposed a so-called Bayesian Averaging of Classical Estimates (BACE) approach to check the robustness of different explanatory variables in growth regressions. This approach builds upon the approach as suggested by Sala-i-Martin (1997) in the sense that different specifications are estimated (by OLS) to check the sensitivity of the coefficient estimate of the variable of interest. The major innovation of BACE as compared to Sala-i-Martin's approach is that there is no set of fixed variables included and the number of explanatory variables in the specifications is flexible. The biggest disadvantages of the BACE approach are the need of having a balanced data set, i.e. an equal number of observations for all regressions (due to the chosen weighting scheme), the restriction of limiting the list of potential variables to be less than the number of observations and the computational burden. For a recent application see Lamla (2006). 
Table 5: Physical integrity rights and terror, 111 countries, test for robustness

\begin{tabular}{|c|c|c|c|c|c|c|c|c|}
\hline & (1) & (2) & (3) & (4) & (5) & (6) & (7) & (8) \\
\hline Lagged endogenous & 0.532 & 0.536 & 0.538 & 0.531 & 0.532 & 0.495 & 0.644 & 0.306 \\
\hline & $(23.17)^{\star \star \star}$ & $(23.41)^{\star \star \star}$ & $(23.60)^{\star \star \star}$ & $(22.98)^{\star \star \star}$ & $(22.02)^{\star \star \star}$ & $(9.77)^{\star \star \star}$ & $(27.59)^{\star \star \star}$ & $(6.29)^{\star \star \star}$ \\
\hline Income lower middle & $\begin{array}{l}0.001 \\
(0.02)\end{array}$ & $\begin{array}{l}-0.033 \\
(0.40)\end{array}$ & $\begin{array}{l}-0.034 \\
(0.41)\end{array}$ & $\begin{array}{l}-0.028 \\
(0.34)\end{array}$ & $\begin{array}{l}-0.008 \\
(0.09)\end{array}$ & $\begin{array}{l}-0.034 \\
(0.24)\end{array}$ & $\begin{array}{l}-0.019 \\
(0.24)\end{array}$ & $\begin{array}{l}-0.128 \\
(0.50)\end{array}$ \\
\hline Income upper middle & $\begin{array}{c}0.280 \\
(2.70)^{\star \star \star}\end{array}$ & $\begin{array}{c}0.252 \\
(2.31)^{\star \star}\end{array}$ & $\begin{array}{c}0.253 \\
(2.35)^{\star \star}\end{array}$ & $\begin{array}{c}0.257 \\
(2.31)^{\star \star}\end{array}$ & $\begin{array}{c}0.226 \\
(1.94)^{\star}\end{array}$ & $\begin{array}{c}0.466 \\
(2.65)^{\star \star \star}\end{array}$ & $\begin{array}{c}0.252 \\
(2.60)^{\star \star \star}\end{array}$ & $\begin{array}{l}0.483 \\
(1.65)\end{array}$ \\
\hline Income high OECD & $\begin{array}{c}1.170 \\
(7.30)^{\star \star \star}\end{array}$ & $\begin{array}{c}1.112 \\
(6.76)^{\star \star \star}\end{array}$ & $\begin{array}{c}1.118 \\
(6.75)^{\star \star \star}\end{array}$ & $\begin{array}{c}1.172 \\
(7.42)^{\star \star \star}\end{array}$ & $\begin{array}{c}1.158 \\
(6.57)^{\star \star \star}\end{array}$ & $\begin{array}{c}1.501 \\
(5.96)^{\star \star \star}\end{array}$ & $\begin{array}{c}1.024 \\
(6.84)^{\star \star \star}\end{array}$ & $\begin{array}{c}2.060 \\
(7.64)^{\star \star \star}\end{array}$ \\
\hline Income high & $\begin{array}{l}0.125 \\
(0.86)\end{array}$ & $\begin{array}{l}0.077 \\
(0.56)\end{array}$ & $\begin{array}{l}0.051 \\
(0.35)\end{array}$ & $\begin{array}{l}0.165 \\
(1.27)\end{array}$ & $\begin{array}{l}0.143 \\
(1.22)\end{array}$ & $\begin{array}{l}0.267 \\
(1.39)\end{array}$ & $\begin{array}{l}0.370 \\
(1.77)^{\star}\end{array}$ & $\begin{array}{l}0.352 \\
(1.14)\end{array}$ \\
\hline Legal origin British & $\begin{array}{c}-0.897 \\
(5.02)^{\star \star \star}\end{array}$ & $\begin{array}{c}-0.903 \\
(4.76)^{\star \star \star}\end{array}$ & $\begin{array}{c}-0.898 \\
(4.74)^{\star \star \star}\end{array}$ & $\begin{array}{c}-0.859 \\
(4.66)^{\star \star \star}\end{array}$ & $\begin{array}{c}-0.782 \\
(3.36)^{\star \star \star}\end{array}$ & $\begin{array}{c}-0.999 \\
(3.61)^{\star \star \star}\end{array}$ & $\begin{array}{l}0.046 \\
(0.26)\end{array}$ & $\begin{array}{c}0.299 \\
(1.70)^{\star}\end{array}$ \\
\hline Legal origin French & $\begin{array}{c}-0.979 \\
(5.16)^{\star \star \star}\end{array}$ & $\begin{array}{c}-1.002 \\
(5.01)^{\star \star \star}\end{array}$ & $\begin{array}{c}-0.996 \\
(4.96)^{\star \star \star}\end{array}$ & $\begin{array}{c}-0.929 \\
(4.81)^{\star \star \star}\end{array}$ & $\begin{array}{c}-0.835 \\
(3.44)^{\star \star \star}\end{array}$ & $\begin{array}{c}-1.074 \\
(3.82)^{\star \star \star}\end{array}$ & $\begin{array}{l}0.035 \\
(0.20)\end{array}$ & $\begin{array}{l}0.035 \\
(0.19)\end{array}$ \\
\hline Legal origin Socialist & $\begin{array}{c}-0.695 \\
(3.21)^{\star \star \star}\end{array}$ & $\begin{array}{c}-0.701 \\
(3.07)^{\star \star \star}\end{array}$ & $\begin{array}{c}-0.694 \\
(3.03)^{\star \star \star}\end{array}$ & $\begin{array}{c}-0.650 \\
(2.93)^{\star \star \star}\end{array}$ & $\begin{array}{c}-0.603 \\
(2.25)^{\star \star}\end{array}$ & $\begin{array}{c}-0.711 \\
(2.26)^{\star \star}\end{array}$ & $\begin{array}{c}0.387 \\
(1.94)^{\star}\end{array}$ & $\begin{array}{c}0.837 \\
(2.53)^{\star \star}\end{array}$ \\
\hline Legal origin German & $\begin{array}{c}-1.126 \\
(3.65)^{\star \star \star}\end{array}$ & $\begin{array}{c}-1.143 \\
(3.72)^{\star \star \star}\end{array}$ & $\begin{array}{c}-1.140 \\
(3.71)^{\star \star \star}\end{array}$ & $\begin{array}{c}-1.133 \\
(3.68)^{\star \star \star}\end{array}$ & $\begin{array}{c}-1.040 \\
(3.16)^{\star \star \star}\end{array}$ & $\begin{array}{c}-1.496 \\
(3.40)^{\star \star \star}\end{array}$ & $\begin{array}{l}-0.387 \\
(1.55)\end{array}$ & $\begin{array}{l}-0.403 \\
(1.16)\end{array}$ \\
\hline Population (log) & $\begin{array}{c}-0.186 \\
(8.49)^{\star \star \star}\end{array}$ & $\begin{array}{c}-0.198 \\
(8.97)^{\star \star \star}\end{array}$ & $\begin{array}{c}-0.200 \\
(9.08)^{\star \star \star}\end{array}$ & $\begin{array}{c}-0.195 \\
(8.74)^{\star \star \star}\end{array}$ & $\begin{array}{c}-0.177 \\
(7.55)^{\star \star \star}\end{array}$ & $\begin{array}{c}-0.270 \\
(6.71)^{\star \star \star}\end{array}$ & $\begin{array}{c}-0.229 \\
(8.75)^{\star \star \star}\end{array}$ & $\begin{array}{c}-0.446 \\
(8.22)^{\star \star \star}\end{array}$ \\
\hline Democracy & $\begin{array}{c}0.020 \\
(3.34)^{\star \star \star}\end{array}$ & $\begin{array}{c}0.018 \\
(3.09)^{\star \star \star \star}\end{array}$ & $\begin{array}{c}0.017 \\
(2.92)^{\star \star \star \star}\end{array}$ & $\begin{array}{c}0.021 \\
(3.61)^{\star \star \star}\end{array}$ & $\begin{array}{c}0.023 \\
(4.10)^{\star \star \star}\end{array}$ & $\begin{array}{c}0.016 \\
(1.80)^{*}\end{array}$ & $\begin{array}{c}0.020 \\
(3.19)^{\star \star \star \star}\end{array}$ & $\begin{array}{c}0.033 \\
(2.81)^{\star \star \star}\end{array}$ \\
\hline Terror events, dummy & $\begin{array}{c}-0.188 \\
(2.80)^{\star \star \star}\end{array}$ & & & & & & & \\
\hline Number of severe terror events & & $\begin{array}{c}-0.007 \\
(3.69)^{\star \star \star}\end{array}$ & & & & & & \\
\hline Number of domestic terror events & & & $\begin{array}{c}-0.002 \\
(2.99)^{\star \star \star \star}\end{array}$ & & & & & \\
\hline Number of international terror events & & & & $\begin{array}{c}-0.019 \\
(4.86)^{\star \star \star}\end{array}$ & & & & \\
\hline Number of terror events & & & & & $\begin{array}{c}-0.025 \\
(5.62)^{\star \star \star}\end{array}$ & $\begin{array}{c}-0.003 \\
(4.73)^{\star \star \star}\end{array}$ & $\begin{array}{l}-0.014 \\
(1.80)^{*}\end{array}$ & $\begin{array}{c}-0.005 \\
(4.58)^{\star \star \star}\end{array}$ \\
\hline Method & Ordered Probit & Ordered Probit & Ordered Probit & Ordered Probit & Ordered Probit & Ordered Probit & 2SLS & GMM \\
\hline Observations & 2217 & 2217 & 2217 & 2217 & 1676 & 541 & 1846 & 2217 \\
\hline Years & $1982-2002$ & 1982-2002 & $1982-2002$ & $1982-2002$ & 1982-1997 & $1998-2002$ & $1982-2002$ & $1982-2002$ \\
\hline Pseudo R2 & 0.31 & 0.32 & 0.31 & 0.31 & 0.31 & 0.33 & 0.72 & \\
\hline $\begin{array}{l}\text { Sargan test (p-value) } \\
\text { First stage F-statistic }\end{array}$ & & & & & & & $\begin{array}{c}0.07 \\
24.87\end{array}$ & 0.55 \\
\hline AR(1) test ( $p$-value) & & & & & & & & 0.00 \\
\hline AR(2) test ( $p$-value) & & & & & & & & 0.33 \\
\hline
\end{tabular}

Absolute value of $t$ statistics in parentheses

* significant at $10 \%$; ** significant at $5 \%$; *** significant at $1 \%$

Dummy for each year included. 
Table 6: Civil liberties and terror, 111 countries, test for robustness

\begin{tabular}{|c|c|c|c|c|c|c|c|c|}
\hline & (1) & (2) & (3) & (4) & (5) & (6) & (7) & (8) \\
\hline Lagged endogenous & 1.827 & 1.825 & 1.826 & 1.825 & 1.724 & 2.779 & 0.836 & 0.819 \\
\hline & $(17.41)^{\star \star \star}$ & $(17.34)^{\star \star \star}$ & $(17.35)^{\star \star \star}$ & $(17.33)^{\star \star \star}$ & $(15.86)^{\star \star \star}$ & $(296.03)^{\star \star \star}$ & $(61.57)^{\star \star \star}$ & $(8.28)^{\star \star \star}$ \\
\hline Income lower middle & $\begin{array}{l}0.088 \\
(1.25)\end{array}$ & $\begin{array}{l}0.097 \\
(1.41)\end{array}$ & $\begin{array}{l}0.095 \\
(1.39)\end{array}$ & $\begin{array}{l}0.101 \\
(1.48)\end{array}$ & $\begin{array}{l}0.103 \\
(1.44)\end{array}$ & $\begin{array}{c}0.172 \\
(5.27)^{\star \star \star}\end{array}$ & $\begin{array}{l}0.030 \\
(1.10)\end{array}$ & $\begin{array}{l}0.084 \\
(1.28)\end{array}$ \\
\hline Income upper middle & $\begin{array}{c}0.292 \\
(2.95)^{\star \star \star}\end{array}$ & $\begin{array}{c}0.298 \\
(3.01)^{\star \star \star}\end{array}$ & $\begin{array}{c}0.298 \\
(3.01)^{\star \star \star}\end{array}$ & $\begin{array}{c}0.303 \\
(3.03)^{\star \star \star}\end{array}$ & $\begin{array}{c}0.281 \\
(2.68)^{\star \star \star}\end{array}$ & $\begin{array}{c}0.481 \\
(12.64)^{\star \star \star}\end{array}$ & $\begin{array}{c}0.092 \\
(2.73)^{\star \star \star}\end{array}$ & $\begin{array}{l}0.157 \\
(1.62)\end{array}$ \\
\hline Income high OECD & $\begin{array}{c}1.390 \\
(7.61)^{\star \star \star}\end{array}$ & $\begin{array}{c}1.404 \\
(7.85)^{\star \star \star}\end{array}$ & $\begin{array}{c}1.405 \\
(7.81)^{\star \star \star \star}\end{array}$ & $\begin{array}{c}1.452 \\
(8.42)^{\star \star \star \star}\end{array}$ & $\begin{array}{c}1.416 \\
(7.82)^{\star \star \star}\end{array}$ & $\begin{array}{c}1.687 \\
(34.30)^{\star \star \star}\end{array}$ & $\begin{array}{c}0.262 \\
(5.33)^{\star \star \star}\end{array}$ & $\begin{array}{c}0.407 \\
(2.28)^{\star \star}\end{array}$ \\
\hline Income high & $\begin{array}{l}-0.030 \\
(0.26)\end{array}$ & $\begin{array}{l}0.007 \\
(0.06)\end{array}$ & $\begin{array}{l}-0.010 \\
(0.08)\end{array}$ & $\begin{array}{l}0.053 \\
(0.43)\end{array}$ & $\begin{array}{l}0.037 \\
(0.30)\end{array}$ & $\begin{array}{c}0.330 \\
(9.32)^{\star \star \star}\end{array}$ & $\begin{array}{l}-0.018 \\
(0.25)\end{array}$ & $\begin{array}{l}-0.029 \\
(0.34)\end{array}$ \\
\hline Legal origin British & $\begin{array}{l}-0.293 \\
(0.76)\end{array}$ & $\begin{array}{l}-0.280 \\
(0.72)\end{array}$ & $\begin{array}{l}-0.281 \\
(0.72)\end{array}$ & $\begin{array}{l}-0.233 \\
(0.60)\end{array}$ & $\begin{array}{l}-0.201 \\
(0.49)\end{array}$ & $\begin{array}{c}-4.502 \\
(147.31)^{\star \star \star}\end{array}$ & $\begin{array}{l}-0.009 \\
(0.16)\end{array}$ & $\begin{array}{l}0.046 \\
(1.17)\end{array}$ \\
\hline Legal origin French & $\begin{array}{l}-0.412 \\
(1.07)\end{array}$ & $\begin{array}{l}-0.393 \\
(1.01)\end{array}$ & $\begin{array}{l}-0.395 \\
(1.01)\end{array}$ & $\begin{array}{l}-0.324 \\
(0.83)\end{array}$ & $\begin{array}{l}-0.285 \\
(0.70)\end{array}$ & $\begin{array}{c}-4.618 \\
(124.02)^{\star \star \star}\end{array}$ & $\begin{array}{l}-0.035 \\
(0.60)\end{array}$ & $\begin{array}{l}0.010 \\
(0.25)\end{array}$ \\
\hline Legal origin Socialist & $\begin{array}{l}-0.419 \\
(1.03)\end{array}$ & $\begin{array}{l}-0.414 \\
(1.01)\end{array}$ & $\begin{array}{l}-0.410 \\
(1.00)\end{array}$ & $\begin{array}{l}-0.370 \\
(0.91)\end{array}$ & $\begin{array}{l}-0.386 \\
(0.89)\end{array}$ & $\begin{array}{c}-4.619 \\
(134.42)^{\star \star \star}\end{array}$ & $\begin{array}{l}0.011 \\
(0.16)\end{array}$ & $\begin{array}{l}0.024 \\
(0.22)\end{array}$ \\
\hline Legal origin German & $\begin{array}{l}-0.580 \\
(1.35)\end{array}$ & $\begin{array}{l}-0.575 \\
(1.33)\end{array}$ & $\begin{array}{l}-0.575 \\
(1.33)\end{array}$ & $\begin{array}{l}-0.535 \\
(1.24)\end{array}$ & $\begin{array}{l}-0.473 \\
(1.03)\end{array}$ & $\begin{array}{c}-5.101 \\
(111.43)^{\star \star \star}\end{array}$ & $\begin{array}{l}0.031 \\
(0.36)\end{array}$ & $\begin{array}{l}-0.003 \\
(0.05)\end{array}$ \\
\hline Population (log) & $\begin{array}{c}-0.083 \\
(4.45)^{\star \star \star}\end{array}$ & $\begin{array}{c}-0.076 \\
(4.16)^{\star \star \star}\end{array}$ & $\begin{array}{c}-0.079 \\
(4.31)^{\star \star \star}\end{array}$ & $\begin{array}{c}-0.070 \\
(3.88)^{\star \star \star}\end{array}$ & $\begin{array}{c}-0.064 \\
(3.33)^{\star \star \star}\end{array}$ & $\begin{array}{c}-0.064 \\
(25.01)^{\star \star \star}\end{array}$ & $\begin{array}{c}-0.039 \\
(4.27)^{\star \star \star}\end{array}$ & $\begin{array}{l}-0.029 \\
(1.62)\end{array}$ \\
\hline Democracy & $\begin{array}{c}0.045 \\
(5.22)^{\star \star \star}\end{array}$ & $\begin{array}{c}0.046 \\
(5.32)^{\star \star \star}\end{array}$ & $\begin{array}{c}0.046 \\
(5.28)^{\star \star \star}\end{array}$ & $\begin{array}{c}0.048 \\
(5.47)^{\star \star \star}\end{array}$ & $\begin{array}{c}0.047 \\
(4.99)^{\star \star \star}\end{array}$ & $\begin{array}{c}0.073 \\
(19.70)^{\star \star \star}\end{array}$ & $\begin{array}{c}0.023 \\
(6.86)^{\star \star \star}\end{array}$ & $\begin{array}{l}0.023 \\
(1.33)\end{array}$ \\
\hline Terror events, dummy & $\begin{array}{l}0.027 \\
(0.54)\end{array}$ & & & & & & & \\
\hline Number of severe terror events & & $\begin{array}{l}-0.005 \\
(2.23)^{\star *}\end{array}$ & & & & & & \\
\hline Number of domestic terror events & & & $\begin{array}{l}-0.001 \\
(1.68)^{\star}\end{array}$ & & & & & \\
\hline Number of international terror events & & & & $\begin{array}{l}-0.012 \\
(2.57)^{\star \star}\end{array}$ & & & & \\
\hline Number of terror events & & & & & $\begin{array}{c}-0.013 \\
(2.83)^{\star \star \star}\end{array}$ & $\begin{array}{c}-0.002 \\
(11.46)^{\star \star \star}\end{array}$ & $\begin{array}{l}0.002 \\
(0.78)\end{array}$ & $\begin{array}{l}-0.000 \\
(0.51)\end{array}$ \\
\hline Method & Ordered Probit & Ordered Probit & Ordered Probit & Ordered Probit & Ordered Probit & Ordered Probit & $2 S L S$ & GMM \\
\hline Observations & 3218 & 3218 & 3218 & 3218 & 2671 & 547 & 2325 & 3218 \\
\hline Years & 1973-2002 & 1973-2002 & 1973-2002 & 1973-2002 & 1973-1997 & 1998-2002 & 1973-2002 & 1973-2003 \\
\hline Pseudo R2 & 0.65 & 0.65 & 0.65 & 0.65 & 0.63 & 0.78 & 0.93 & \\
\hline Sargan test ( $p$-value) & & & & & & & 0.37 & 0.13 \\
\hline First stage F-statistic & & & & & & & 30.60 & \\
\hline AR(1) test (p-value) & & & & & & & & 0.00 \\
\hline$A R(2)$ test ( $p$-value) & & & & & & & & 0.10 \\
\hline
\end{tabular}

Absolute value of $t$ statistics in parentheses

* significant at 10\%; ** significant at $5 \%$; *** significant at $1 \%$

Dummy for each year included. 
governments' respect for human rights at the one percent level of significance (columns 1 to 6). We see that splitting among the time dimension and differentiating between domestic and international terror does not qualitatively change the previous results. Furthermore, the significantly smaller (at the 1 percent level) coefficient of domestic terror gives mild support to our conjecture that hypothesis 3 is "more" valid for domestic forms of terror. Note, however, that the net effect is still negative.

Column 7 shows the 2SLS results. Our instruments - voting in line with the US in the United Nations General Assembly and government fractionalization - are not rejected by the Sargan test at the five percent level of significance (while they are at the ten percent level). The first stage F-test indicates the power of these instruments, as they easily pass the threshold of 10 proposed by Staiger and Stock (1997). As can be seen, the (negative) impact of terror on human rights remains marginally significant.

Column 8 reports results from the GMM estimator. Again, the results remain qualitatively unchanged, with the impact of terror being significant at the one percent level. ${ }^{24}$ Both the Hansen test and the Arellano-Bond test do clearly not reject the specification. We take this as evidence that endogeneity is not an issue here and that our previous results are valid.

Table 6 replicates the analysis for civil liberties. According to the estimates, the impact of terror on civil liberties is less robust as compared to those on physical integrity rights. Still, the impact stays significant in the two sub-samples. The same is true when we focus on severe terrorism only, and distinguish domestic from international terror. In the instrumental variables and GMM regressions, and when employing a dummy for terror events, however, the impact of terror is no longer significant at conventional levels. To some extent this is not surprising. The civil liberties index is sometimes used as an indicator of democracy. As we already control for democracy by including the Polity IV index, part of the explanatory power of civil liberties is absorbed. To some extent our results also support Abadie (2006) showing democracy to influence terror. If civil liberties to some extent capture democracy and causality runs from democracy to terror, it is not

\footnotetext{
${ }^{24}$ We also estimated the GMM setup for the number of suicide attacks and the number of people killed. All previous findings remain unchanged.
} 
surprising that the correlation between terror and civil liberties does not hold in the instrumental variables regression.

\title{
Table 7: Human rights and terror, Extreme Bounds Analysis
}

\author{
Physical integrity \\ Physical integrity (lagged) \\ Population (log) \\ Democracy \\ Number of terror events \\ Civil liberties \\ Civil liberties (lagged) \\ Population (log) \\ Democracy \\ Number of terror events
}

Avg. Beta Avg.Std.Err \% Sign. CDF(0) lower Bound upper Bound

\begin{tabular}{|cccccc|}
\hline 0.545 & 0.039 & 1.000 & 1.000 & -16.425 & 57.761 \\
-0.260 & 0.045 & 0.999 & 0.999 & -32.177 & 27.984 \\
0.032 & 0.011 & 0.863 & 0.971 & -28.559 & 16.393 \\
\hline & & & & & \\
\hline-0.008 & 0.003 & 0.937 & 0.985 & -23.343 & 16.507 \\
\hline \multicolumn{7}{l}{} & & & & & \\
\hline 3.329 & 0.149 & 1.000 & 1.000 & -24.515 & 685.185 \\
-0.112 & 0.036 & 0.949 & 0.968 & -39.301 & 96.045 \\
0.059 & 0.017 & 0.840 & 0.931 & -33.347 & 16.109 \\
\hline & & & & & \\
\hline-0.017 & 0.002 & 0.768 & 0.934 & -5.451 & 0.635 \\
\hline
\end{tabular}

Notes:

Results for physical integrity (civil liberties) are based on 22724 (16877) combinations with 1140 (1771)

observations, on average.

Dummies for income, legal origin and years included in all regressions.

Appendix A contains the 52 variables included in the EBA.

Table 7 reports the results of the Extreme Bounds Analysis. As can be seen in the upper part of the table, the $\operatorname{CDF}(0)$ of the three base variables easily exceeds the threshold of 0.95 when we focus on physical integrity rights. Lagged physical integrity and population size have a $\operatorname{CDF}(0)$ of almost one, while that of democracy is 0.97 . The former two variables are significant at the five percent level in all of the more than 23,000 regressions run; democracy is significant in 86 percent of these regressions. Turning to our variable of main interest - the number of terror events in a given country and year - the table shows that the $\mathrm{CDF}(0)$ also easily exceeds the critical threshold of 0.95 (and is in fact close to one). At the five percent level of significance, the number of terror events is significant in 94 percent of the regressions run. We conclude that our result is indeed robust to the inclusion of other variables suggested in the human rights literature.

Turning to civil liberties, the lower part of the table shows that there is no robust impact of terror. While the results for the other variables are more or less similar to those described above, the number of terror events exert a significant impact on civil liberties in only 77 percent of the regressions run. The $\operatorname{CDF}(0)$ of 0.93 confirms that the impact of 
terror events on civil liberties can not be considered to be completely robust according to standard criteria.

\section{Conclusion}

Our analysis suggests a rise in the level of terror to significantly reduce governments' respect for basic human rights. According to our results, terror substantially increases the probability of extrajudicial killings, political imprisonment, and torture, especially in countries with a high level of human rights. This result is extremely robust, as Extreme Bounds Analysis for more than 23,000 regressions shows. To some extent, civil liberties (measured by the Freedom House index) are also restricted as a consequence of terrorism. However, these results are not completely robust to the specification of the model. We find no effect of terror on "positive rights" such as political participation, freedom of religion, freedom of speech, or freedom of movement. ${ }^{25}$

Our results also show that the effect of terror strongly depends on the level of human rights. For low levels of physical integrity terror increases human rights, while terror reduces rights when governments' respect for physical integrity rights is high. As can be seen, the marginal effects are always significant at the one percent level. These results are in line with our hypotheses. Overall, terror reduces human rights. However, the impact becomes generally stronger when human rights are a priori more prevalent. Terror even increases human rights when hitting countries with initially low respect for human rights.

Our theoretical model points to the trade off between security and human rights, namely, that, experiencing a threat of terror, citizens demand more security at the expense of human rights. The empirical results indeed indicate that governments' answer to terror is - on average - to restrict freedom. Our study supports anecdotal evidence suggesting that governments - under the threat of terror - violate those very rights they want to protect from terror in the first place. Which policy conclusions do arise from this? Clearly, if human rights restrictions really increase security, people might be willing to trade some of their rights for greater security. However, whether and to what extent

\footnotetext{
${ }^{25}$ Note that our data do not cover the major time of the "war against terror" in the aftermath of $9 / 11$. The results do thus not depend on this exceptional event.
} 
human rights violations increase security is indeed not at all obvious. This is even more true, as our analysis shows that governments reduce physical human rights as a consequence of terror, rather than civil liberties or empowerment rights. Following Frey and Luechinger (2003) and Freytag et al. (2006), restricting human rights respect in reaction to terror attacks may reduce the individual opportunity costs of potential terrorists, and thus rather increase terrorism. Frey and Luechinger argue that there may be superior strategies than deterrence in fighting terrorism. The same could hold true for restricting human rights as an answer to terrorism. 


\section{References}

Abadie, Alberto, 2006, Poverty, Political Freedom, and the Roots of Terrorism, American Economic Review 96, 2: 50-56.

Acemoglu, Daron and James A. Robinson, 2001, A Theory of Political Transitions, American Economic Review 91, 4: 938-963.

Alesina, Alberto; William Easterly; Arnaud Devleeschauwer; Sergio Kurlat and Romain Wacziarg, 2003, Fractionalization, Journal of Economic Growth 8, 2: 155-194.

Amnesty International, 2006, Amnesty International Report 2006, London, UK: Amnesty International.

Arellano, Manuel and Steven Bond, 1991, Some Tests for Specification for Panel Data: Monte Carlo Evidence and an Application to Employment Equations, Review of Economic Studies 58, 2: 277-297.

Arellano, Manuel and Olympia Bover, 1995, Another Look at the Instrumental Variable Estimation of Error-components Models, Journal of Econometrics 68, 1: 29-51.

Barro, Robert J. and Jong-Wha Lee, 2000, International Data on Educational Attainment: Updates and Implications, CID Working Paper No. 42.

Beck, Thorsten; George Clarke; Alberto Groff; Philip Keefer and Patrick Walsh, 2001, New Tools in Comparative Political Economy: The Database of Political Institutions, World Bank Economic Review 15, 1: 165-176.

Black, Duncan, 1948, On the Rational of Group Decision Making, Journal of Political Economy 56, 1: 23-34.

Blundell, Richard and Steven Bond, 1998, Initial Conditions and Moment Restrictions in Dynamic Panel Data Models, Journal of Econometrics 87, 1: 115-143.

Boockmann, Bernhard and Axel Dreher, 2003, The Contribution of the IMF and the World Bank to Economic Freedom, European Journal of Political Economy 19, 3: 633-649.

Cingranelli, David L. and David L. Richards, 1999, Measuring the Level, Pattern, and Sequence of Government Respect for Physical Integrity Rights, International Studies Quarterly 43, 2: 407-418. 
Cingranelli, David L. and David L. Richards, 2006, The Cingranelli-Richards (CIRI) Human Rights Dataset 2006, 9/27/2006, http://www.humanrightsdata.org/.

Cole, David and James X. Dempsey, 2002, Terrorism and the Constitution, New York (NY): New York Press.

de Haan, Jakob and Jan-Egbert Sturm, 2000, On the Relationship between Economic Freedom and Economic Growth, European Journal of Political Economy 16, 2: 215-241.

Downs, Anthony, 1957, An Economic Theory of Democracy, New York (NY): Harper and Row.

Dreher, Axel, 2006, IMF and Economic Growth: The Effects of Programs, Loans, and Compliance with Conditionality, World Development 34, 5: 769-788.

Dreher, Axel and Martin Gassebner, 2006, Does Political Proximity to the U.S. Cause Terror? mimeo.

Dreher, Axel and Lars Siemers, 2006, Do Globalization and Economic Freedom Affect Human Rights? An Empirical Analysis, mimeo.

Dreher, Axel and Roland Vaubel, 2005, Foreign Exchange Intervention and the Political Business Cycle: A Panel Data Analysis, mimeo.

Easterly, William and Mirvat Sewadeh, 2001, Global Development Network Growth Database, The World Bank. Economic and Development Research Group.

Economist, The, 2006a, America's Longest War, The Economist, September 2: 20-22.

Economist, The, 2006b, The Freedom Paradox - Liberty Has Been the First Victim of the War Fought in its Name, The Economist, September 2: 22.

Eckstein, Zvi and Daniel Tsiddon, 2004, Macroeconomic Consequences of Terror: Theory and the Case of Israel, Journal of Monetary Economics 51, 5: 971-1002.

Elazar, Daniel, 1996, From Statism to Federalism: A Paradigm Shift, International Political Science Review 17, 4: 417-429.

Enders, Walter and Todd Sandler, 2005, Transnational Terrorism 1968-2000: Thresholds, Persistence, and Forecasts, Southern Economic Journal 71, 3: 467-482.

Enders, Walter and Todd Sandler, 2006, Distribution of Transnational Terrorism among Countries by Income Class and Geography after 9/11, International Studies Quarterly 50, 2: 367-394. 
Eubank, William L. and Leonhard B. Weinberg, 2001, Terrorism and Democracy: Perpetradors and Victims, Terrorism and Political Violence 13, 1: 155 - 164.

Freedom House, 2005, Freedom in the World 2005: The Annual Survey of Political Rights and Civil Liberties, Washington, D.C.: Freedom House.

Frey, Bruno S. and Simon Luechinger, 2003, How to Fight Terrorism: Alternatives to Deterrence, Defence and Peace Economics 14, 4: 237-249.

Frey, Bruno S. and Simon Luechinger, 2005, Measuring Terrorism, in: Alain Marciano and Jean-Michel Josselin (eds.) Law and the State: A Political Economy Approach: New Horizons in Law and Economics, Cheltenham, UK: Edward Elgar Publishing: 142-181.

Frey, Bruno S.; Simon Luechinger and Alois Stutzer, 2007, Calculating Tragedy: Assessing the Costs of Terrorism, Journal of Economic Surveys 21, 1: 1-24.

Freytag, Andreas; Jens J. Krüger and Friedrich Schneider, 2006, The Origins of Terrorism. Cross-Country Estimates with Discrete Choice and Count Data Methods, mimeo.

Gallup, John L.; Andrew D. Mellinger and Jeffrey D. Sachs, 2001, Geography Datasets, http://www.cid.harvard.edu/.

Ghosn, Faten; Glenn Palmer and Stuart Bremer, 2004, The MID3 Data Set, 1993-2001: Procedures, Coding Rules, and Description, Conflict Management and Peace Science 21, 2: 133-154.

Gurr, Ted; Keith Jaggers and Will Moore, 2003, Polity IV Handbook, Boulder (CO): University of Colorado Press.

Heston, Alan; Robert Summers and Bettina Aten, 2002, Penn World Tables, Version 6.1, Center for International Comparisons (CICUP), University of Pennsylvania.

UNDP, 2005, Human Development Report - International cooperation at a crossroads: Aid, trade and security in an unequal world.

Inklaar, Robert, Richard Jong-A-Pin and Jakob de Haan, 2005, Trade and Business Cycle Synchronization in OECD Countries: A Re-examination, CESifo Working Paper No. 1546. 
Kaufmann, Daniel, 2004, Human Rights and Governance: The Empirical Challenge, Paper prepared for the "Human Rights and Development: Towards Mutual Reinforcement" conference at New York University Law School.

Krueger, Alan B. and Jitka Malečková, 2003, Education, Poverty and Terrorism: Is there a Causal Connection? Journal of Economic Perspectives 17, 4: 119-144.

Lamla, Michael, 2006, The Long-run Determinants of Pollution, mimeo.

Leamer, Edward E., 1983, Let's Take the Con out of Econometrics, American Economic Review 73, 1: 31-43.

Levine, Ross and David Renelt, 1992, A Sensitivity Analysis of Cross-Country Growth Regressions, American Economic Review 82, 4: 942-963.

Marshall, Monty G. and Keith Jaggers, 2000, Polity IV Project: Political Regime Characteristics and Transitions, 1800-2000, http://www.cidcm.umd.edu/inscr/ polity/.

Persson, Torsten and Guido Tabellini, 2000, Political Economics. Explaining Economic Policy, Cambridge (MA): MIT Press.

Persson, Torsten and Guido Tabellini, 2003, The Economic Effect of Constitutions: What Do the Data Say? Cambridge (MA): MIT Press.

Richards, David L.; Ronald Gelleny and David Sacko. 2001. Money with a Mean Streak? Foreign Economic Penetration and Government Respect for Human Rights in Developing Countries, International Studies Quarterly 45, 2: 219-239.

Risen, James and Eric Lichtblau, 2005, Bush Lets U.S. Spy on Callers without Courts, New York Times, December 16.

Roodman, David, 2006, How to Do xtabond2: An Introduction to "Difference" and "System" GMM in Stata, Center for Global Development Working Paper 103.

Sala-i-Martin, Xavier, 1997, I Just Ran Two Million Regressions, American Economic Review 87, 2: 178-183.

Sala-i-Martin, Xavier; Gernot Doppelhofer and Ronald I. Miller, 2004, Determinants of Long-term Growth: A Bayesian Averaging of Classical Estimates (BACE) Approach, American Economic Review 94, 4: 813-835.

Sandler, Todd, 2003, Collective Action and Transnational Terrorism, World Economy 16, 6: 779-802. 
Sandler, Todd, 2005, Collective versus Unilateral Responses to Terrorism, Public Choice 124, 1-2: 75-93.

Staiger, Douglas and James H. Stock, 1997, Instrumental Variables Regression with Weak Instruments, Econometrica 65, 3: 557-586.

Sturm, Jan-Egbert; Helge Berger and Jakob de Haan, 2005, Which Variables Explain Decisions on IMF Credit? An Extreme Bounds Analysis, Economics \& Politics 17, 2: 177-213.

Sturm, Jan-Egbert and Jakob de Haan, 2005, Determinants of Long-term Growth: New Results Applying Robust Estimation and Extreme Bounds Analysis, Empirical Economics 30, 3: 597-617.

Treisman, Daniel, 2000, Decentralization and the Quality of Government, mimeo.

Union of International Associations, 2000, Yearbook of International Organizations, Thomson, Munich.

Windmeijer, Frank, 2005, A Finite Sample Correction for the Variance of Linear Efficient Two-step GMM Estimators, Journal of Econometrics 126, 1: 25-51.

World Bank, 2001, Cross-National Data on Government Employment \& Wages.

World Bank, 2006, World Development Indicators, CD-Rom, Washington, D.C. 


\section{Appendix A: Definitions and data sources}

\begin{tabular}{|c|c|}
\hline Variable & Description \\
\hline Number of terror events & Number of terror events in respective country and year. \\
\hline Number of suicide attacks & Number of suicide attacks in respective country and year. \\
\hline Number of people killed & Number of people killed in respective country and year. \\
\hline Terror events, dummy & $\begin{array}{l}1 \text { if at least on terror event occurred in respective country } \\
\text { and year. }\end{array}$ \\
\hline $\begin{array}{l}\text { Number of severe terror } \\
\text { events }\end{array}$ & $\begin{array}{l}\text { Number of terror events in which at least one person was } \\
\text { killed or injured in respective country and year. }\end{array}$ \\
\hline $\begin{array}{l}\text { Number of domestic } \\
\text { terror events }\end{array}$ & $\begin{array}{l}\text { Number of terror events in which both the attacker and the } \\
\text { target was domestic in respective country and year. }\end{array}$ \\
\hline $\begin{array}{l}\text { Number of international } \\
\text { terror events }\end{array}$ & $\begin{array}{l}\text { Number of terror events in which either the attacker or the } \\
\text { target was from abroad in respective country and year. }\end{array}$ \\
\hline Physical integrity & $\begin{array}{l}\text { The composite index of physical integrity rights is the } \\
\text { additive of torture, extrajudicial killings, political } \\
\text { imprisonments, and disappearance, ranging from } 0-8 \text {. }\end{array}$ \\
\hline Empowerment index & $\begin{array}{l}\text { The composite index of empowerment rights is the additive } \\
\text { of freedom of movements, freedom of speech, workers' } \\
\text { rights, political participation, and freedom of religion } \\
\text { indicators, ranging from } 0-10 \text {. }\end{array}$ \\
\hline Civil liberties & $\begin{array}{l}\text { The survey based index combines four subcategories: (a) } \\
\text { Freedom of Expression and Belief, (b) Associational and } \\
\text { Organizational Rights, (c) Rule of Law, and (d) Personal } \\
\text { and Individual Rights. }\end{array}$ \\
\hline Imprisonment & $\begin{array}{l}\text { Subindex of physical integrity: number of political } \\
\text { imprisonments. }\end{array}$ \\
\hline Torture & Subindex of physical integrity: number of tortures. \\
\hline Disappearences & Subindex of physical integrity: number of disappearances. \\
\hline Kills & $\begin{array}{l}\text { Subindex of physical integrity: number of extrajudicial } \\
\text { killings. }\end{array}$ \\
\hline Democracy & $\begin{array}{l}\text { Measures the general openness of political institutions on } \\
\text { the scale }-10-10(-10=\text { low; } 10=\text { high }) \text {. }\end{array}$ \\
\hline Population (log) & Natural logarithm of a country's population. \\
\hline Income, dummies & $\begin{array}{l}\text { Dummies for income. The groups are: low } \$ 825 \text { or less; } \\
\text { lower middle, } \$ 826-3,255 \text {; upper middle, } \$ 3,256-10,065 \text {; } \\
\text { and high (OECD), } \$ 10,066 \text { or more. }\end{array}$ \\
\hline Legal origin, dummies & $\begin{array}{l}\text { Dummies for British, French, Socialist, and German legal } \\
\text { origin. }\end{array}$ \\
\hline
\end{tabular}

Source

\begin{tabular}{|l|}
\hline MIPT Terrorism Knowledge \\
Base \\
MIPT Terrorism Knowledge \\
Base \\
MIPT Terrorism Knowledge \\
Base \\
MIPT Terrorism Knowledge \\
Base \\
MIPT Terrorism Knowledge \\
Base \\
MIPT Terrorism Knowledge \\
Base \\
MIPT Terrorism Knowledge \\
Base \\
Cingranelli and Richards \\
(2006) \\
Cingranelli and Richards \\
(2006) \\
Easterly and Sewadeh (2001) \\
Freedom House (2005) \\
World Bank (2006) \\
World Bank (2006) \\
(2006) \\
Cingranelli and Richards \\
$(2006)$ \\
Cingranelli and Richards \\
(2006) \\
Cingranelli and Richards \\
(2006) \\
Marshall and Jaggers (2000) \\
\end{tabular}

\section{Variables used in Extreme Bounds Analysis}

\begin{tabular}{|l|}
\hline Political risk \\
Number of wars \\
Years of independence \\
Age of democracy \\
New state, dummy
\end{tabular}

\begin{tabular}{|l|}
\hline International Country Risk \\
Guide \\
Ghosn et al. (2004) \\
Persson and Tabellini (2003) \\
Persson and Tabellini (2003) \\
Gallup et al. (2001) \\
\hline
\end{tabular}


Variable

Government

Fractionalization

Federalism, dummy

Years in office

Constituency

Left government, dummy

Vertical imbalance

Tiers

Tiers, average

Revenue decentralization

Government transfers

Government employees

Special interests

Pre-election, legislature

Pre-election, executive

Post election, legislature

Post election, executive

Election year, legislative

Age of parties

Years left

GDP per capita

GDP

Investment

Investment growth

Debt service

FDI

Trade

Growth

Urban population

Infant mortality

Human Development

Indicator

IMF program, dummy

World Bank projects

Urban population

Area

Government debt

Life expectancy

Number of human rights

organizations

Gap in schooling

Primary schooling

Protestant share

Catholic Share

Fractionalization

Ethnic fractionalization

Language

Religious fractionalization

Dominant religion
The probability that two deputies picked at random from among the government parties will be of different parties.

Dummy for federal states.

Indicates the number of years the government chief executive has been in office.

Indicates whether the constituencies of the senators are states/provinces

Indicates whether the main government party is left-wing.

Intergovernmental transfers as a share of sub-national expenditures.

Number of government tiers.

Average area first tier units (thousands square kilometers per unit).

Sub-national Revenues (\% of total revenues)

Transfers to sub-national from other levels of Government (\% of total sub-national revenues and grants).

Share of government employees in total employment.

Sub-national Tax Revenue (\% of total sub-national

revenues and grants).

Dummy for special interest executive parties.

Share of the year within 12 months of a legislative election.

Share of the year within 12 months of an executive

election.

Share of the year within after 12 months of a legislative election.

Share of the year within after 12 months of an executive election.

Dummy for legislative elections.

Average age of political parties.

Number of years the government chief executive remains in office.

Real GDP per capita in constant dollars (in international prices, base 1985).

GDP in current US\$.

Gross capital formation (percent of GDP).

Gross capital formation (annual percent growth).

Public and publicly guaranteed debt service (percent of GNI).

Foreign direct investment, net inflows (percent of GDP).

Exports and Imports (in percent of GDP).

GDP growth (annual, percent).

Urban population (percent of total)

Mortality rate, infant (per 1,000 live births).

Composite index based on measures of life expectancy,

literacy, education, and standards of living.

IMF program is at least five months in effect in a given

year.

Number of World Bank projects at least five months in

effect in a given year.

Urban population (percent of total)

Land area (square kilometer).

Central government debt, total (percent of GDP).

Life expectancy at birth, total (years).

Number of human rights related NGOs being represented

in a country.

Difference between years of schooling male and years of schooling female.

Average years of primary schooling in the total population.

Share of protestants in population.

Share of catholics in population.

Index of ethnolinguistic fractionalization, approximating

the level of lack of ethnic and linguistic cohesion within a

country, ranging from 0 (homogeneous) to 1 (strongly

fractionalized) and averaging 5 different indexes.

Index of ethnic fractionalization.

Index of language fractionalization.

Index of religious fractionalization.

Percent of dominant religion.
Source

Beck et al. (2001)

Elazar (1996)

Beck et al. (2001)

Beck et al. (2001)

Beck et al. (2001)

IMF's Government Finance

Statistics

Treisman (2000)

Treisman (2000)

IMF's Government Finance Statistics

IMF's Government Finance

Statistics

World Bank (2001)

Beck et al. (2001)

Dreher and Vaubel (2005)

Dreher and Vaubel (2005)

Dreher and Vaubel (2005)

Dreher and Vaubel (2005)

Beck et al. (2001)

Beck et al. (2001)

Beck et al. (2001)

Heston, Summers and Aten (2002)

World Bank (2006)

World Bank (2006)

World Bank (2006)

World Bank (2006)

World Bank (2006)

World Bank (2006)

World Bank (2006)

World Bank (2006)

World Bank (2006)

UNDP (2005)

Dreher (2006)

Boockmann and Dreher (2003)

World Bank (2006)

World Bank (2006)

World Bank (2006)

World Bank (2006)

Union of International

Associations (2000)

Barro and Lee (2000)

Barro and Lee (2000)

Persson and Tabellini (2003)

Persson and Tabellini (2003)

Persson and Tabellini (2003)

Alesina et al. (2003)

Alesina et al. (2003)

Alesina et al. (2003)

Alesina et al. (2003) 


\section{Appendix B: Descriptive Statistics}

\begin{tabular}{|l|}
\hline Variable \\
\hline Number of terror events \\
Number of suicide attacks \\
Number of people killed \\
Terror events, dummy \\
Number of severe terror events \\
Number of domestic terror events \\
Number of international terror events \\
Physical integrity \\
Empowerment index \\
Civil liberties \\
Imprisonment \\
Torture \\
Disappearences \\
Kills \\
Democracy, index \\
Population size (log) \\
Lower middle income, dummy \\
Higher middle income, dummy \\
High income OECD, dummy \\
High income, dummy \\
British legal origin, dummy \\
French legal origin, dummy \\
Socialist legal origin, dummy \\
German legal origin, dummy \\
\hline
\end{tabular}

\begin{tabular}{|c|}
\hline Mean \\
\hline \\
\hline 2.68 \\
0.05 \\
3.49 \\
0.27 \\
0.97 \\
1.39 \\
1.29 \\
4.86 \\
5.88 \\
4.10 \\
1.09 \\
0.80 \\
1.65 \\
1.32 \\
0.22 \\
15.15 \\
0.26 \\
0.19 \\
0.12 \\
0.15 \\
0.34 \\
0.48 \\
0.10 \\
0.04 \\
\hline
\end{tabular}

Minimum

\begin{tabular}{|c|}
\hline 0.00 \\
0.00 \\
0.00 \\
0.00 \\
0.00 \\
0.00 \\
0.00 \\
0.00 \\
0.00 \\
1.00 \\
0.00 \\
0.00 \\
0.00 \\
0.00 \\
-10.00 \\
9.89 \\
0.00 \\
0.00 \\
0.00 \\
0.00 \\
0.00 \\
0.00 \\
0.00 \\
0.00 \\
\hline
\end{tabular}

Maximum

\begin{tabular}{|c|}
\hline 858 \\
72 \\
2987 \\
1.00 \\
551 \\
611 \\
247 \\
8.00 \\
10.00 \\
7.00 \\
2.00 \\
2.00 \\
2.00 \\
2.00 \\
10.00 \\
20.98 \\
1.00 \\
1.00 \\
1.00 \\
1.00 \\
1.00 \\
1.00 \\
1.00 \\
1.00 \\
\hline
\end{tabular}

Standard Deviation

\begin{tabular}{|c|}
\hline 18.44 \\
1.23 \\
50.32 \\
0.44 \\
8.68 \\
15.09 \\
5.62 \\
2.37 \\
3.28 \\
1.95 \\
0.85 \\
0.75 \\
0.65 \\
0.78 \\
7.58 \\
2.10 \\
0.44 \\
0.39 \\
0.32 \\
0.36 \\
0.47 \\
0.50 \\
0.30 \\
0.20 \\
\hline
\end{tabular}




\section{CESifo Working Paper Series}

(for full list see www.cesifo-group.de)

1872 Hans Gersbach and Bernhard Pachl, Cake Division by Majority Decision, December 2006

1873 Gunther Schnabl, The Evolution of the East Asian Currency Baskets - Still Undisclosed and Changing, December 2006

1874 Horst Raff and Michael J. Ryan, Firm-Specific Characteristics and the Timing of Foreign Direct Investment Projects, December 2006

1875 Jukka Pirttilä and Håkan Selin, How Successful is the Dual Income Tax? Evidence from the Finnish Tax Reform of 1993, December 2006

1876 Agnieszka Stążka, Sources of Real Exchange Rate Fluctuations in Central and Eastern Europe - Temporary or Permanent?, December 2006

1877 Xavier Calsamiglia, Teresa Garcia-Milà and Therese J. McGuire, Why do Differences in the Degree of Fiscal Decentralization Endure?, December 2006

1878 Natacha Gilson, How to be Well Shod to Absorb Shocks? Shock Synchronization and Joining the Euro Zone, December 2006

1879 Scott Alan Carson, Modern Health Standards for Peoples of the Past: Biological Conditions by Race in the American South, 1873 - 1919, December 2006

1880 Peter Huber, Michael Pfaffermayr and Yvonne Wolfmayr, Are there Border Effects in the EU Wage Function?, December 2006

1881 Harry Flam and Håkan Nordström, Euro Effects on the Intensive and Extensive Margins of Trade, December 2006

1882 Panu Poutvaara and Mikael Priks, Hooliganism in the Shadow of the 9/11 Terrorist Attack and the Tsunami: Do Police Reduce Group Violence?, December 2006

1883 Ruud A. de Mooij and Gaëtan Nicodème, Corporate Tax Policy, Entrepreneurship and Incorporation in the EU, December 2006

1884 Johannes Becker and Clemens Fuest, Corporate Tax Policy and International Mergers and Acquisitions - Is the Tax Exemption System Superior?, January 2007

1885 Momi Dahan and Udi Nisan, The Effect of Benefits Level on Take-up Rates: Evidence from a Natural Experiment, January 2007

1886 José García-Solanes, Francisco I. Sancho-Portero and Fernando Torrejón-Flores, Beyond the Salassa-Samuelson Effect in some New Member States of the European Union, January 2007 
1887 Peter Egger, Wolfgang Eggert and Hannes Winner, Saving Taxes Through Foreign Plant Ownership, January 2007

1888 Timothy J. Goodspeed and Andrew Haughwout, On the Optimal Design of Disaster Insurance in a Federation, January 2007

1889 Wim Groot, Henriëtte Maassen van den Brink and Bernard van Praag, The Compensating Income Variation of Social Capital, January 2007

1890 Bas Jacobs, Ruud A. de Mooij and Kees Folmer, Analyzing a Flat Income Tax in the Netherlands, January 2007

1891 Hans Jarle Kind, Guttorm Schjelderup and Frank Stähler, Newspapers and Advertising: The Effects of Ad-Valorem Taxation under Duopoly, January 2007

1892 Erkki Koskela and Rune Stenbacka, Equilibrium Unemployment with Outsourcing under Labour Market Imperfections, January 2007

1893 Maarten Bosker, Steven Brakman, Harry Garretsen, Herman de Jong and Marc Schramm, The Development of Cities in Italy 1300 - 1861, January 2007

1894 Michel Beine, Oscar Bernal, Jean-Yves Gnabo and Christelle Lecourt, Intervention Policy of the BoJ: A Unified Approach, January 2007

1895 Robert S. Chirinko and Daniel J. Wilson, State Investment Tax Incentives: A Zero-Sum Game?, January 2007

1896 Theo S. Eicher and Oliver Roehn, Sources of the German Productivity Demise Tracing the Effects of Industry-Level ICT Investment, January 2007

1897 Helge Berger, Volker Nitsch and Tonny Lybek, Central Bank Boards around the World: Why does Membership Size Differ?, January 2007

1898 Gabriel Felbermayr and Wilhelm Kohler, Does WTO Membership Make a Difference at the Extensive Margin of World Trade?, January 2007

1899 Benno Torgler and Friedrich Schneider, The Impact of Tax Morale and Institutional Quality on the Shadow Economy, January 2007

1900 Tomer Blumkin and Efraim Sadka, On the Desirability of Taxing Charitable Contributions, January 2007

1901 Frederick van der Ploeg and Reinhilde Veugelers, Higher Education Reform and the Renewed Lisbon Strategy: Role of Member States and the European Commission, January 2007

1902 John Lewis, Hitting and Hoping? Meeting the Exchange Rate and Inflation Criteria during a Period of Nominal Convergence, January 2007 
1903 Torben M. Andersen, The Scandinavian Model - Prospects and Challenges, January 2007

1904 Stephane Dees, Sean Holly, M. Hashem Pesaran and L. Vanessa Smith, Long Run Macroeconomic Relations in the Global Economy, January 2007

1905 Richard Jong-A-Pin and Jakob De Haan, Political Regime Change, Economic Reform and Growth Accelerations, January 2007

1906 Sascha O. Becker and Peter H. Egger, Endogenous Product versus Process Innovation and a Firm's Propensity to Export, February 2007

1907 Theo S. Eicher, Chris Papageorgiou and Oliver Roehn, Unraveling the Fortunates of the Fortunate: An Iterative Bayesian Model Averaging (IBMA) Approach, February 2007

1908 Liliana E. Pezzin, Robert A. Pollak and Barbara S. Schone, Efficiency in Family Bargaining: Living Arrangements and Caregiving Decisions of Adult Children and Disabled Elderly Parents, February 2007

1909 Christian Keuschnigg and Soren Bo Nielsen, Self-Selection and Advice in Venture Capital Finance, February 2007

1910 Rune Jansen Hagen and Gaute Torsvik, Irreversible Investments, Dynamic Inconsistency and Policy Convergence, February 2007

1911 Eric A. Hanushek and Ludger Woessmann, The Role of School Improvement in Economic Development, February 2007

1912 Bernard M. S. van Praag, Perspectives from the Happiness Literature and the Role of New Instruments for Policy Analysis, February 2007

1913 Volker Grossmann and Thomas M. Steger, Growth, Development, and Technological Change, February 2007

1914 Margarita Katsimi and Thomas Moutos, Human Capital and the Feldstein-Horioka Puzzle, February 2007

1915 Oliver Roehn, Theo S. Eicher and Thomas Strobel, The Ifo Industry Growth Accounting Database, February 2007

1916 Ian Babetskii, Aggregate Wage Flexibility in Selected New EU Member States, February 2007

1917 Burkhard Heer, Alfred Maussner and Paul D. McNelis, The Money-Age Distribution: Empirical Facts and Limited Monetary Models, February 2007

1918 Yin-Wong Cheung, Menzie D. Chinn and Eijii Fujii, The Overvaluation of Renminbi Undervaluation, February 2007 
1919 Jim Malley, Apostolis Philippopoulos and Ulrich Woitek, To React or Not? Fiscal Policy, Volatility and Welfare in the EU-3, February 2007

1920 Mattias Polborn, Competing for Recognition through Public Good Provision, February 2007

1921 Lars P. Feld and Benno Torgler, Tax Morale after the Reunification of Germany: Results from a Quasi-Natural Experiment, February 2007

1922 Robert S. Chirinko and Huntley Schaller, Fundamentals, Misvaluation, and Investment: The Real Story, February 2007

1923 Benno Torgler and Friedrich Schneider, Shadow Economy, Tax Morale, Governance and Institutional Quality: A Panel Analysis, February 2007

1924 Adrian Pagan and M. Hashem Pesaran, On Econometric Analysis of Structural Systems with Permanent and Transitory Shocks and Exogenous Variables, February 2007

1925 Hans-Werner Sinn, The Welfare State and the Forces of Globalization, February 2007

1926 Michael Smart, Raising Taxes through Equalization, February 2007

1927 Øystein Foros, Kåre P. Hagen and Hans Jarle Kind, Price-Dependent Profit Sharing as an Escape from the Bertrand Paradox, February 2007

1928 Balázs Égert, Kirsten Lommatzsch and Amina Lahrèche-Révil, Real Exchange Rates in Small Open OECD and Transition Economies: Comparing Apples with Oranges?, February 2007

1929 Aleksander Berentsen and Cyril Monnet, Monetary Policy in a Channel System, February 2007

1930 Wolfgang Ochel, The Free Movement of Inactive Citizens in the EU - A Challenge for the European Welfare State?, February 2007

1931 James K. Hammitt and Nicolas Treich, Statistical vs. Identified Lives in Benefit-Cost Analysis, February 2007

1932 Wilhelm Kohler, The Bazaar Effect, Unbundling of Comparative Advantage, and Migration, February 2007

1933 Karsten Staehr, Fiscal Policies and Business Cycles in an Enlarged Euro Area, February 2007

1934 Michele Bernasconi and Paola Profeta, Redistribution or Education? The Political Economy of the Social Race, March 2007

1935 Axel Dreher, Martin Gassebner and Lars-H. R. Siemers, Does Terror Threaten Human Rights? Evidence from Panel Data, March 2007 